\title{
Formation of Iron-Rich Intermetallic Phases in Al-7Si-Mg: Influence of Cooling Rate and Strontium Modification
}

\begin{abstract}
JORGE SANTOS, ANDERS E.W. JARFORS, and ARNE K. DAHLE
The influence of cooling rate on the formation of iron-rich intermetallic phases during solidification of unmodified and strontium-modified $\mathrm{Al}-7 \mathrm{Si}-0.3 \mathrm{Mg}$ alloys has been investigated. The effect of strontium on the intermetallic phases was evaluated in unquenched and quenched samples. Samples were quenched before the start of the Al-Si eutectic reaction, along the Al-Si eutectic reaction and just after the end of solidification. The results show that the addition of strontium increased the size of both $\beta-\mathrm{Al}_{5} \mathrm{FeSi}$ and $\pi-\mathrm{Al}_{8} \mathrm{FeMg}_{3} \mathrm{Si}_{6}$ at low cooling rates. For unmodified and strontium-modified alloys, an increase of cooling rate resulted in a decrease in size of the intermetallic phases, particularly in the strontium modified alloy. In the strontium modified alloy quenched before the start of the Al-Si eutectic reaction, $\pi-\mathrm{Al}_{8} \mathrm{FeMg}_{3} \mathrm{Si}_{6}$ appeared as thin platelets at the eutectic cell boundaries. Chinese script-like $\pi-\mathrm{Al}_{8} \mathrm{FeMg}_{3} \mathrm{Si}_{6}$ and platelet-like $\beta-\mathrm{Al}_{5} \mathrm{FeSi}$ intermetallic phases were observed uniformly distributed in the eutectic regions in the unmodified alloy quenched before the start of the eutectic reaction. Strontium modified semi-solid Al-7Si-0.3Mg castings were produced and the type of intermetallic phase, morphology, size, area fraction and distribution were similar to that observed in the strontium modified alloy quenched before the start of the Al-Si eutectic reaction.
\end{abstract}

https://doi.org/10.1007/s11661-019-05343-5

(C) The Author(s) 2019

\section{INTRODUCTION}

AL-7SI-MG alloys have good castability, corrosion resistance and high-specific strength, particularly in the heat-treated condition. ${ }^{[1]}$ Al-7Si-Mg castings are used in automotive and aerospace industries and are now starting to become applied in fatigue-critical applications. ${ }^{[2-4]}$ A deep understanding of microstructure and defect formation during solidification is important to produce reliable castings for fatigue-critical applications. ${ }^{[3]}$ Semi-solid metal (SSM) castings typically have low gas entrapment and shrinkage porosity defects compared to high pressure die casting (HPDC). ${ }^{[5]}$ Therefore, aluminum SSM castings can be heat treated to T6 condition to increase the mechanical properties with low blistering occurrence. ${ }^{[5]}$ Typically, initiation of fatigue cracks occurs at defects that are near or at the casting surface such as pores and oxides. ${ }^{[2,3,6]}$ Eutectic silicon, intermetallic phases, magnesium content and cooling rate also influence the fatigue life of

JORGE SANTOS, ANDERS E.W. JARFORS and ARNE K. DAHLE are with the Department of Materials and Manufacturing, School of Engineering, Jönköping University, P.O. Box 1026, 55111 Jönköping, Sweden. Contact e-mail: jorge.santos@ju.se

Manuscript submitted January 29, 2019.

Article published online July 2, 2019
Al-7Si-Mg castings. ${ }^{[2,7,8]}$ Strontium modification is widely used to modify eutectic silicon and consequently improve the mechanical properties of Al-Si alloys. ${ }^{\left[{ }^{2}\right]}$ Al-Si alloys typically contain iron which decreases the ductility and fatigue life of the castings by the formation of iron-rich intermetallic phases. ${ }^{[9]}$ The size, type and volume fraction of iron-rich intermetallic phases formed during solidification of $\mathrm{Al}-7 \mathrm{Si}-\mathrm{Mg}$ alloys depend on the composition of the alloy and solidification conditions. ${ }^{[10,11]}$ Intermetallic phases cannot always be identified by their morphology. ${ }^{[12]}$ The plate-like $\delta$ - $\mathrm{Al}_{3} \mathrm{FeSi}_{2}$ phase may be misidentified as $\beta-\mathrm{Al}_{5} \mathrm{FeSi}$ phase, particularly in modified Al-Si alloys. ${ }^{[13,14]}$ The iron-rich $\delta$ phase is termed as $\delta-\mathrm{Al}_{3} \mathrm{FeSi}_{2}{ }^{[12-15]}$ or $\delta$ - $\mathrm{Al}_{4} \mathrm{FeSi}_{2}{ }^{[16,17]}$ in the literature. In this study, this phase will be described as $\delta-\mathrm{Al}_{3} \mathrm{FeSi}_{2}$. In a strontium modified Al-11.7Si alloy, manganese addition did not result in formation of the script-like $\alpha-\mathrm{Al}_{14} \mathrm{Fe}_{3} \mathrm{Si}_{2}$ phase and instead plate-like intermetallic phases containing manganese were plentiful. ${ }^{[13]} \mathrm{Yu}$ et al. ${ }^{[16]}$ found that the intermetallic phases have a Chinese script morphology in an unmodified cast Al-10Si-0.3Fe alloy, while intermetallic phases with a needle-like morphology were dominant in the strontium modified alloy. Timpel et al. ${ }^{[18]}$ found script-like iron-rich $\alpha-\mathrm{Al}_{14} \mathrm{Fe}_{3} \mathrm{Si}_{2}$ phase in an unmodified Al-10Si-0.1Fe alloy, while the strontium-modified alloy contained $\alpha-\mathrm{Al}_{14} \mathrm{Fe}_{3} \mathrm{Si}_{2}$ phase and a thin platelet $\delta-\mathrm{Al}_{3} \mathrm{FeSi}_{2}$ phase. High silicon contents, cooling rates and strontium modification favors the 
formation of thin platelet $\delta$ - $\mathrm{Al}_{3} \mathrm{FeSi}_{2}$ phase ${ }^{[15,16,19,20]}$ at the expense of the platelet $\beta-\mathrm{Al}_{5} \mathrm{FeSi}$ phase in cast $\mathrm{Al}-\mathrm{Si}$ alloys. Strontium addition promotes the formation of $\delta$ - $\mathrm{Al}_{3} \mathrm{FeSi}_{2}$ phase instead of $\alpha-\mathrm{Al}_{14} \mathrm{Fe}_{3} \mathrm{Si}_{2} .^{[16,18]}$ AlP particles are suggested to act as nucleation sites for the $\beta-\mathrm{Al}_{5} \mathrm{FeSi}$ intermetallic in aluminum foundry alloys. ${ }^{[21,22]}$ Consequently, the addition of strontium can suppress the formation of $\beta-\mathrm{Al}_{5} \mathrm{FeSi}$ phase by poisoning the AlP nuclei dispersed in the liquid. ${ }^{[21,23]}$ However, Samuel et al. ${ }^{[22]}$ reported an increase in the size of $\beta-\mathrm{Al}_{5} \mathrm{FeSi}$ with the addition of strontium in an Al-6.5Si-3.5Cu-Fe alloy. Oxide films are also considered to be favorable nucleation sites for iron-rich intermetallic phases, ${ }^{[21]}$ but less effective compared to AlP particles. ${ }^{[2,25]}$ Additionally, primary $\beta-\mathrm{Al}_{5} \mathrm{FeSi}$ was found to nucleate mostly on/near the $\alpha$-Al phase during solidification of an Al-7.5Si-3.5Cu-0.6Fe alloy. ${ }^{[26]}$ Oxides, pore surfaces and existing $\beta-\mathrm{Al}_{5} \mathrm{FeSi}$ platelets have also been reported to act as nucleation sites for $\beta-\mathrm{Al}_{5} \mathrm{FeSi}^{[26]}$

$\beta-\mathrm{Al}_{5} \mathrm{FeSi}, \pi-\mathrm{Al}_{8} \mathrm{Fe} \mathrm{Mg}_{3} \mathrm{Si}_{6}, \alpha-\mathrm{Al}_{14} \mathrm{Fe}_{3} \mathrm{Si}_{2}$ and $\mathrm{Mg}_{2} \mathrm{Si}$ are intermetallic phases commonly formed during solidification of cast Al-7Si-Mg alloys. ${ }^{[1,27-30]}$ Sjölander and Seifeddine ${ }^{[31]}$ observed $\pi-\mathrm{Al}_{8} \mathrm{FeMg}_{3} \mathrm{Si}_{6}$ phase in directionally solidified $\mathrm{Al}-7 \mathrm{Si}-0.3 \mathrm{Mg}$ for microstructures with a secondary dendrite arm spacing (SDAS) of $10 \mu \mathrm{m}$, while microstructures with SDAS of $51 \mu \mathrm{m}$ additionally contained $\beta-\mathrm{Al}_{5} \mathrm{FeSi}$ and $\mathrm{Mg}_{2} \mathrm{Si}$. The fraction of $\beta-\mathrm{Al}_{5} \mathrm{FeSi}$ was found to decrease with an increase in cooling rate, while the fraction of $\pi-\mathrm{Al}_{8} \mathrm{FeMg}_{3} \mathrm{Si}_{6}$ increased. ${ }^{[31]}$ The high-cooling rate during solidification in the die cavity in HPDC can supress the formation of $\beta-\mathrm{Al}_{5} \mathrm{FeSi}$ to a great extent. ${ }^{[23,32]}$ Therefore, the harmful $\beta-\mathrm{Al}_{5} \mathrm{FeSi}$ can be replaced by intermetallic phases less harmful for mechanical properties. ${ }^{[32]}$ Menargues et $a l^{[33]}$ and Mingo et al. ${ }^{[4]}$ found $\beta-\mathrm{Al}_{5} \mathrm{FeSi}$, $\pi-\mathrm{Al}_{8} \mathrm{FeMg}_{3} \mathrm{Si}_{6}$ and $\mathrm{Mg}_{2} \mathrm{Si}$ in SSM Al-7Si-0.3Mg castings. The formation mechanism of the $\pi-\mathrm{Al}_{8} \mathrm{FeMg}_{3} \mathrm{Si}_{6}$ changes with cooling rate. ${ }^{[31]}$ At low cooling rates, large Chinese script $\pi-\mathrm{Al}_{8} \mathrm{FeMg}_{3} \mathrm{Si}_{6}$ was observed growing on $\beta$ - $\mathrm{Al}_{5} \mathrm{FeSi}$ intermetallics, ${ }^{[31,35]}$ while the $\pi-\mathrm{Al}_{8} \mathrm{FeMg}_{3} \mathrm{Si}_{6}$ phase was smaller and more uniformly distributed in the microstructure at higher cooling rates. ${ }^{[31]}$ The $\pi-\mathrm{Al}_{8} \mathrm{FeMg}_{3} \mathrm{Si}_{6}$ phase can be completely transformed into very fine $\beta-\mathrm{Al}_{5} \mathrm{FeSi}$ platelets during solution treatment of cast $\mathrm{Al}-7 \mathrm{Si}-\mathrm{Mg}$ alloys with magnesium content less than 0.4 wt pct. ${ }^{[3,36,37]}$ However, the coarse platelike $\beta-\mathrm{Al}_{5} \mathrm{FeSi}$ formed during solidification of Al-7Si-Mg alloys does not change in size, number and morphology during T6 heat treatment. ${ }^{[37,38]}$

Previous studies of the solidification sequence of Al-7Si-Mg alloys such as Bäckerud et al. ${ }^{[39]}$ and Wang and Davidson ${ }^{[27]}$ involve cooling rates much lower than in HPDC and SSM casting. Additionally, the majority of studies of the influence of strontium on the formation of intermetallic phases are focused on binary Al-Si base alloys ${ }^{[12,13,16,18,21,40]}$ and a few in the ternary Al-Si-Mg system and are done at low cooling rate. ${ }^{[28,36,41]}$ The present study aims to investigate the effect of strontium and cooling rate on the formation of iron-rich intermetallic phases in a cast $\mathrm{Al}-7 \mathrm{Si}-0.3 \mathrm{Mg}$ alloy. Additionally, the formation of iron-rich intermetallics in strontium-modified rheocast $\mathrm{Al}-7 \mathrm{Si}-\mathrm{Mg}$ was correlated with the effect of cooling rate and strontium modification.

\section{EXPERIMENTAL}

\section{A. Alloys}

Two batches of about $3.5 \mathrm{~kg}$ of $\mathrm{Al}-7 \mathrm{Si}-0.3 \mathrm{Mg}$ alloy were prepared by addition of the intended amount of aluminum, silicon and magnesium in a graphite-bonded silicon carbide crucible and melted at $1023 \mathrm{~K}\left(750{ }^{\circ} \mathrm{C}\right)$ in an electrical resistance furnace. An Al-10 wt pct Fe master alloy was added to increase the iron content of the alloy to $0.2 \mathrm{wt}$ pct to facilitate the detection of iron-rich intermetallic phases in the microstructure. After melting, the alloy was held at $1023 \mathrm{~K}\left(750^{\circ} \mathrm{C}\right)$ for 30 minutes for homogenization. $250 \mathrm{ppm}$ of strontium was added as Al-10 wt pet Sr master alloy rod. After adding the strontium modifier, the melt was stirred for 15 seconds and subsequently a contact time of 20 minutes was allowed before the experiments started. The chemical composition of the unmodified and strontium-modified alloys is shown in Table I.

To produce the SSM castings, about $80 \mathrm{~kg}$ of commercial Al-7Si- $0.3 \mathrm{Mg}$ alloy ingots were melted at $973 \mathrm{~K}$ $\left(700{ }^{\circ} \mathrm{C}\right)$ in a graphite-bonded silicon carbide crucible in an electrical resistance furnace. The average chemical composition of two batches of the commercial Al-7 Si- $0.3 \mathrm{Mg}$ alloy after melting is shown in Table I.

\section{B. Thermal Analysis and Quenching Experiments}

The unmodified and strontium-modified alloys were poured into graphite-bonded silicon carbide crucibles preheated at $973 \mathrm{~K}\left(700{ }^{\circ} \mathrm{C}\right)$. The dimensions and shape of the crucibles can be seen in Figure 1(a). After pouring, the crucibles with the alloy were introduced into a Nabertherm L9/C6 muffle furnace and held at $973 \mathrm{~K}\left(700{ }^{\circ} \mathrm{C}\right)$ for about 15 minutes for equilibration of temperature before thermal analysis and quenching experiments. Next, the crucibles with the alloy were transferred to the experimental setup shown in Figure 1(a). A steel-sheathed type-N thermocouple was immersed in the center of the tapered crucible for thermal analysis and quenching experiments. The thermocouple was calibrated before and after the experimentation using commercial purity aluminum. The calibration temperature was set to $933 \mathrm{~K}\left(660{ }^{\circ} \mathrm{C}\right)$. The average cooling rate in the liquid before nucleation of the first solid was $0.2 \mathrm{~K} / \mathrm{s}$. Three quenching experiments were performed at different stages of the solidification process and just after solidification for both unmodified and strontium-modified alloys. The samples were allowed to cool slowly until the desired quenching temperature was reached, at which the samples were plunged into a water bath at room temperature. The quenching temperatures were determined by monitoring the cooling curves obtained by thermal analysis. Unquenched samples, samples quenched just before the start of the Al-Si eutectic reaction and along the Al-Si eutectic reaction were produced for both 
Table I. Average Chemical Composition of the Three Al-7Si-0.3Mg Alloys Used in This Study. Compositions in Weight Percent

\begin{tabular}{lcccccc}
\hline Alloy & $\mathrm{Si}$ & $\mathrm{Mg}$ & $\mathrm{Fe}$ & $\mathrm{Ti}$ & $\mathrm{Sr}$ & \\
\hline Unmodified Al-7Si-0.3Mg & 6.58 & 0.31 & 0.20 & $<0.0004$ & $<0.0001$ & bal. \\
Strontium Modified Al-7Si-0.3Mg & 6.77 & 0.31 & 0.19 & $<0.0004$ & 0.025 & bal. \\
Commercial Al-7Si-0.3Mg & 7.09 & 0.32 & 0.15 & 0.09 & bal. \\
\hline
\end{tabular}

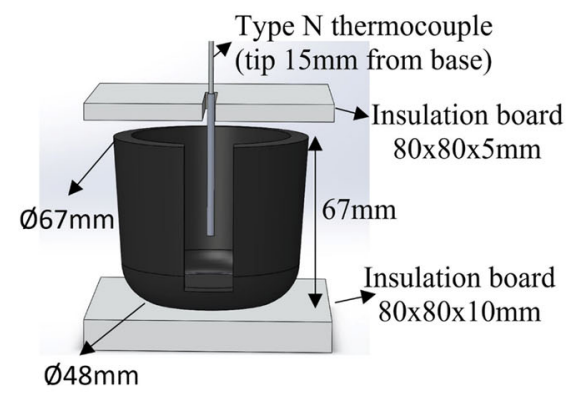

(a)

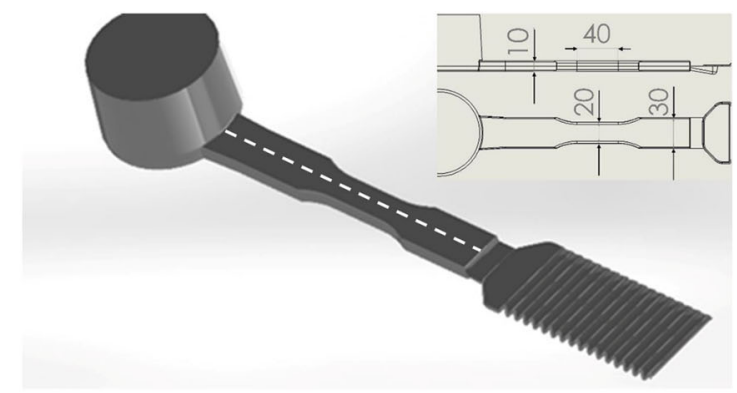

(b)

Fig. 1-(a) Illustration of the experimental setup used for thermal analysis and $(b)$ cast tensile bar. The tensile bar was sectioned along the dashed line. Dimensions in $\mathrm{mm}$.

unmodified and strontium-modified alloys. One sample of each alloy was quenched a few degrees after the end of solidification to avoid any possible dissolution of phases during the slow cooling to room temperature that may occur in the unquenched samples.

\section{SSM Casting}

SSM castings were produced by the Rheometal ${ }^{\mathrm{TM}}{ }^{[42]}$ process. For the slurry preparation, a so-called enthalpy exchange material (EEM) was cast in a copper mold with a cylindrical cavity (diameter $40 \mathrm{~mm}$ and $100 \mathrm{~mm}$ depth) in the center and internal water-cooling channels. The EEM was cast with a $12 \mathrm{~mm}$ diameter stainless steel rod inserted $10 \mathrm{~mm}$ deep into the EEM. After casting, the excess EEM was sectioned to obtain 7 wt pct of the total shot weight. Next, the EEM was preheated in an electrical resistance air circulation furnace at $473 \mathrm{~K}$ $\left(200{ }^{\circ} \mathrm{C}\right)$. A few seconds before immersion into the liquid, the EEM was connected to a stirring device by the steel rod. Around $1.3 \mathrm{~kg}$ of superheated aluminum alloy was collected in a preheated ladle. As the temperature reached $923 \mathrm{~K}\left(650{ }^{\circ} \mathrm{C}\right)\left(\sim 308 \mathrm{~K}\left(35^{\circ} \mathrm{C}\right)\right.$ superheat), the preheated EEM, rotating at about $850 \mathrm{rpm}$, was immersed into the liquid. When the turbulence on the slurry surface stopped, the slurry preparation process was assumed to be complete. The process took about 18 seconds. Subsequently, the prepared slurry was poured into the shot sleeve of a 50 tonne vertical high pressure die casting machine to produce tensile bars as shown in Figure 1(b). The plunger advance speed and intensification pressure applied in the last stage of the casting process were kept constant in all experiments, i.e., $0.3 \mathrm{~m} / \mathrm{s}$ and $160 \mathrm{bar}$, respectively. A duration of 10 seconds was set for the intensification pressure and for the following cooling stage of the casting in the die cavity. The SSM castings for subsequent T5 heat treatment were immediately extracted from the die cavity after the intensification pressure stage and quenched in water at room temperature to minimize precipitation during cooling. The die temperature was controlled by internal oil circulation set at a constant temperature of $448 \mathrm{~K}\left(175^{\circ} \mathrm{C}\right)$, using a PolyTemp HTF 300 heater. To maintain reproducible thermal conditions in the shot sleeve and die cavity, a first set of HPDC castings were produced to warm up the assembly before the experiments began.

\section{Heat Treatment}

The T6 heat treatment started with a solution treatment of the cast tensile bars in an electrical resistance muffle furnace within a period of 24 hours after casting. The solution treatment temperatures and times are shown in Table II. When the solution treatment was completed, the tensile bars were removed from the furnace and immediately quenched in water at room temperature. Next, within a period of 24 hours after quenching the cast tensile bars were artificially aged in an electrical resistance air circulation furnace at the temperatures and times shown in Table II. After the aging was complete the tensile bars were cooled in still air. The holding times shown in Table II are the times that the tensile bars were held at the solution and artificial aging temperatures.

T5 heat treatment consisted of artificial aging performed within 24 hours after SSM casting of the cast tensile bars. The temperatures and times used for the heat treatments in this work are based on a separate study of optimized heat treatment procedure.

\section{E. Microstructural Characterization}

The thermal analysis and quenched samples were sectioned close to the thermocouple tip, while SSM cast tensile bars were sectioned along the dashed line shown in Figure 1(b). Samples were prepared for metallography and after the last step of polishing with $1 \mu \mathrm{m}$ 
diamond suspension, the samples were etched in a $10 \mathrm{pct}$ $\mathrm{NaOH}$ solution. For Scanning Electron Microscopy (SEM), the last step of polishing was completed with OP-U suspension.

Energy-dispersive X-ray spectroscopy (EDS) was used to identify the intermetallic phases detected in the different samples. A fixed acceleration voltage of $10 \mathrm{kV}$ was used in a JEOL JSM-7001F SEM equipped with EDS detector. EDS maps were used to identify the intermetallic phases in the different castings. Additionally, the composition of iron-rich intermetallics was measured by EDS point analysis and a minimum of ten intermetallics were analyzed.

The manual point count method from ASTM E562-11 ${ }^{[43]}$ was used for determination of area fraction of the different intermetallic phases on SEM micrographs. Ten different regions were analyzed for each sample. The magnification used for determination of area fraction of the different intermetallic phases varied from $100 \times$ for the samples with coarser microstructures to $500 \times$ for the samples with refined microstructure.

The size of the different iron-rich phases was determined by measurement of the longest line segment that could be drawn within the contour of the intermetallic phase. The longest line segment length of at least 15 iron-rich intermetallics phase were measured on optical micrographs of each specimen.

\section{F. Differential Scanning Calorimetry}

Differential scanning calorimetry (DSC) of samples from SSM cast tensile bars was performed in a NETZSCH 404 DSC. Baselines were obtained by DSC measurements of empty crucibles. Cylinders with $5 \mathrm{~mm}$ diameter were machined from the center of the cast tensile bars in the different conditions. Next, the cylinders were cut transversely with a precision cut-off machine to obtain discs with a mass of $42 \pm 2 \mathrm{mg}$. The discs for DSC analysis from each condition were inserted into a platinum-rhodium crucible coated with $\mathrm{Al}_{2} \mathrm{O}_{3}$. The crucible and disc were heated to 933 $\left(660{ }^{\circ} \mathrm{C}\right)$ at a rate of $10 \mathrm{~K} / \mathrm{min}$, held for 5 minutes, and then cooled to $313 \mathrm{~K}\left(40{ }^{\circ} \mathrm{C}\right)$ at the same rate. This is called the first melting cycle. When the temperature reached $313 \mathrm{~K}\left(40{ }^{\circ} \mathrm{C}\right)$, the samples were held for 15 minutes and then the previous cycle was repeated. This is called the second melting cycle. During the DSC analysis, argon was circulated through the system at a rate of $20 \mathrm{~mL} / \mathrm{min}$ to minimize oxidation. Three discs from each condition were tested. The characteristic temperatures were determined by a change of the first derivative $(\mathrm{d} T / \mathrm{d} t){ }^{[44]}$

\section{RESULTS}

\section{A. Thermal Analysis}

The cooling curves and respective first derivative curves for unmodified and strontium-modified Al-7Si- $0.3 \mathrm{Mg}$ alloys are shown in Figure 2. Four reaction peaks were observed in the unmodified alloy and three reaction peaks in the strontium modified alloy. Reaction 3 observed in the cooling curve of the unmodified alloy was not observed in the strontium modified alloy-see Figure 2. The start temperatures of the solidification reactions detected in the cooling curves are shown in Table III. The suggested reactions presented in Table III were identified by comparison of the reaction temperatures obtained from the cooling curves in Figure 2 with those of Bäckerud et al. ${ }^{[39]}$ and Wang and Davidson. ${ }^{[27]}$

In the unmodified alloy, solidification starts with the formation of $\alpha-\mathrm{Al}$ dendrites (peak reaction 1 in Figure 2) followed by the Al-Si eutectic reaction (peak reaction 2 in Figure 2). The two thermal arrests that occur at $842 \mathrm{~K}$ and $827 \mathrm{~K}\left(569{ }^{\circ} \mathrm{C}\right.$ and $\left.554{ }^{\circ} \mathrm{C}\right)$ likely resulted from the ternary eutectic reaction $\mathrm{L} \rightarrow \mathrm{Al}+\mathrm{Si}$ $+\beta-\mathrm{Al}_{5} \mathrm{FeSi}$ and the quaternary eutectic reaction $\mathrm{L} \rightarrow$ $\mathrm{Al}+\mathrm{Si}+\pi-\mathrm{Al}_{8} \mathrm{FeMg}_{3} \mathrm{Si}_{6}+\mathrm{Mg}_{2} \mathrm{Si}$, respectively. The addition of strontium resulted in a decrease of the $\mathrm{Al}-\mathrm{Si}$ eutectic reaction temperature of about $6 \mathrm{~K}$, as commonly reported in the literature. ${ }^{[21,45,46]}$ Additionally, the reaction peak 3 is not obtained in the cooling curve of the strontium-modified alloy. However, the quaternary eutectic reaction that occurs at about $827 \mathrm{~K}$ $\left(554^{\circ} \mathrm{C}\right)$ produced a more significant thermal arrest in the cooling curve of the strontium modified alloy compared to the unmodified alloy.

Figure 3 shows the solidification paths of Al-7Si-0.3Mg- $0.2 \mathrm{Fe}$ alloys without and with $250 \mathrm{ppm}$ strontium calculated by Thermocalc ${ }^{\mathrm{TM}}$ using the Scheil-Gulliver model. The different colors observed along the curves in Figure 3 denote a certain range of temperatures at which stable phases can form during solidification. The numbers associated to each color region of the curves were selected to match the reactions detected on thermal analysis curves, as shown in Figure 2. The solidification sequence of the Al-7Si- $0.3 \mathrm{Mg}-0.2 \mathrm{Fe}$ alloy without strontium predicted by Thermocalc ${ }^{\mathrm{TM}}$ correlates well with the suggested reactions of the unmodified alloy listed in Table III. Thermocalc ${ }^{\mathrm{TM}}$ shows no effect of strontium addition on the Al-Si eutectic and ternary eutectic $\mathrm{L} \rightarrow \mathrm{Al}+\mathrm{Si}+$ $\beta-\mathrm{Al}_{5} \mathrm{FeSi}$ reactions, as shown in Figure 3. However, the formation of $\beta-\mathrm{Al}_{5} \mathrm{FeSi}$ phase is constrained to a smaller range of temperatures with the addition of strontium, as seen in Figure 3, i.e., the addition of strontium results in the formation of slightly less $\beta-\mathrm{Al}_{5} \mathrm{FeSi}$ and more $\pi-\mathrm{Al}_{8} \mathrm{FeMg}_{3} \mathrm{Si}_{6}$ phase compared to the alloy without strontium according to Thermocalc ${ }^{\mathrm{TM}}$.

\section{B. Unquenched and Quenched Samples}

Figure 4 shows optical micrographs of unquenched and quenched unmodified and strontium modified alloys. Figures 5 and 6 show SEM micrographs with respective EDS mapping of silicon, magnesium and iron for the unmodified and strontium-modified alloys, respectively. The average compositions of iron-rich intermetallic phases were measured in selected samples as shown in Table IV. The identification of the intermetallic phases observed in the optical micrographs in 
Table II. Heat Treatments Conducted for the SSM Castings

\begin{tabular}{lcc}
\hline Casting & Condition & Temperature/Holding Time \\
\hline SSM Al-7Si-0.3Mg & T5 & $448 \mathrm{~K}\left(175^{\circ} \mathrm{C}\right) / 4.5 \mathrm{~h}$ \\
& T6 & $783 \mathrm{~K}\left(510^{\circ} \mathrm{C}\right) / 4 \mathrm{~h}+463 \mathrm{~K}\left(190{ }^{\circ} \mathrm{C}\right) / 2 \mathrm{~h}$ \\
\hline
\end{tabular}

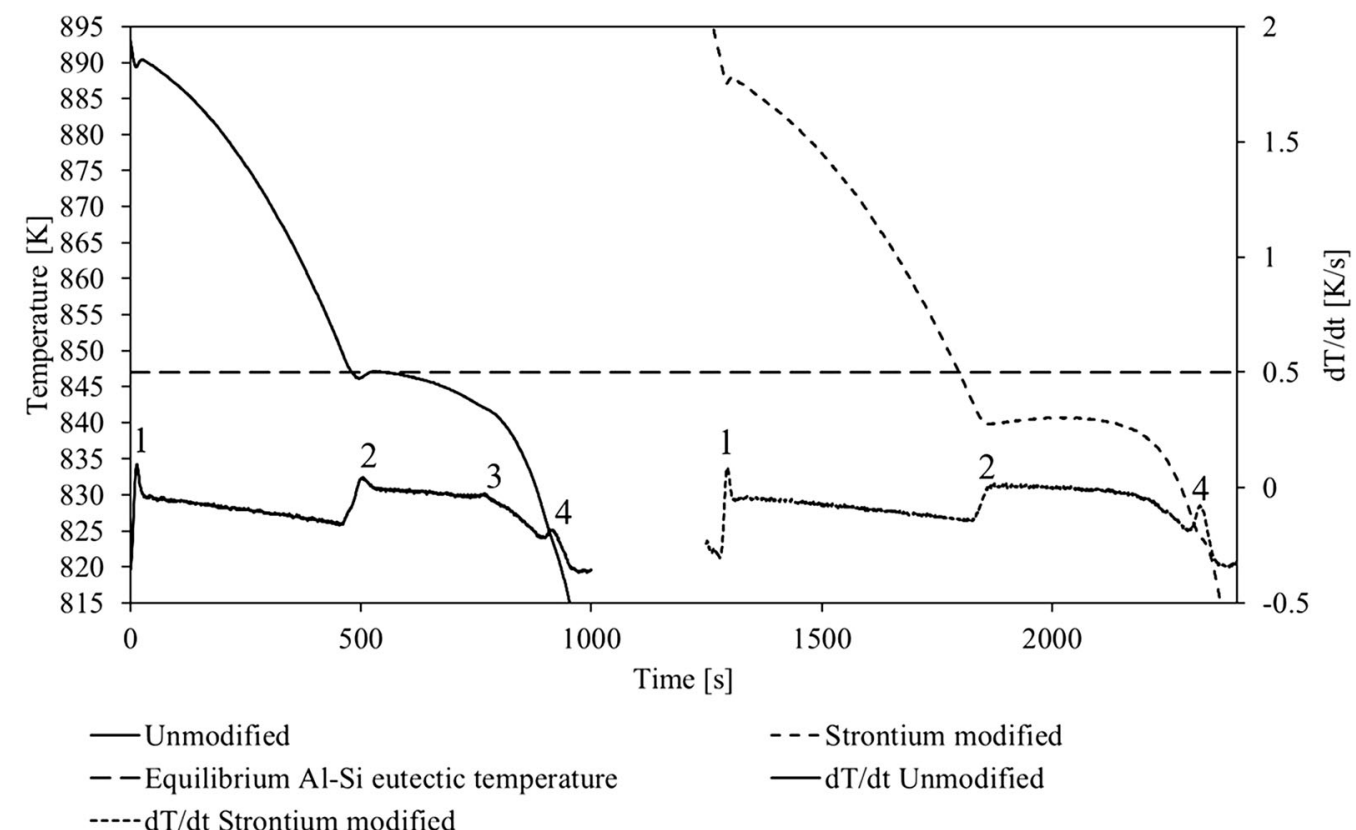

Fig. 2 - Cooling and first-derivative curves obtained for the unmodified and strontium-modified alloys. The horizontal broken line shows the equilibrium Al-Si eutectic temperature of $847 \mathrm{~K}\left(574{ }^{\circ} \mathrm{C}\right)$ obtained from Thermocalc ${ }^{\mathrm{TM}}$. The peak reactions revealed by the first derivative curves are numbered 1 to 4 . The cooling curve and respective first-derivative curve of the strontium-modified sample has been shifted along the time axis for clarity.

Table III. Solidification Reactions and Start Temperatures for the Unmodified and Strontium-Modified Alloys

\begin{tabular}{|c|c|c|}
\hline & Suggested Reactions ${ }^{[27,39]}$ & Start Temperature $\left(\mathrm{K}\left({ }^{\circ} \mathrm{C}\right)\right)$ \\
\hline \multirow[t]{4}{*}{ Unmodified } & $1-\mathrm{L} \rightarrow \mathrm{Al}$ dendrites & $889.7(616.7)$ \\
\hline & $2-\mathrm{L} \rightarrow \mathrm{Al}+\mathrm{Si}$ eutectic & $849.2(576.2)$ \\
\hline & $3-\mathrm{L} \rightarrow \mathrm{Al}+\mathrm{Si}+\beta-\mathrm{Al}_{5} \mathrm{FeSi}$ & $842.4(569.4)$ \\
\hline & $4-\mathrm{L} \rightarrow \mathrm{Al}+\mathrm{Si}+\pi-\mathrm{Al}_{8} \mathrm{FeMg}_{3} \mathrm{Si}_{6}+\mathrm{Mg}_{2} \mathrm{Si}$ & $826.8(553.8)$ \\
\hline \multirow[t]{4}{*}{ Modified } & $1-\mathrm{L} \rightarrow \mathrm{Al}$ dendrites & $887.4(614.4)$ \\
\hline & $2-\mathrm{L} \rightarrow \mathrm{Al}+\mathrm{Si}$ eutectic & $842.9(569.9)$ \\
\hline & $3-\mathrm{L} \rightarrow \mathrm{Al}+\mathrm{Si}+\beta-\mathrm{Al}_{5} \mathrm{FeSi}$ & not detected \\
\hline & $4-\mathrm{L} \rightarrow \mathrm{Al}+\mathrm{Si}+\pi-\mathrm{Al}_{8} \mathrm{FeMg}_{3} \mathrm{Si}_{6}+\mathrm{Mg}_{2} \mathrm{Si}$ & $827.1(554.1)$ \\
\hline
\end{tabular}

Figure 4 was based on analysis of the average composition of the phase, EDS mapping and literature. ${ }^{[10,27,31,47]}$ The intermetallic phases observed in as-cast Al-7Si-Mg alloys are typically $\beta-\mathrm{Al}_{5} \mathrm{FeSi}$, $\pi-\mathrm{Al}_{8} \mathrm{FeMg}_{3} \mathrm{Si}_{6}$ and $\mathrm{Mg}_{2} \mathrm{Si}^{[10,27,31,47]}$ The $\pi-\mathrm{Al}_{8} \mathrm{FeMg}_{3} \mathrm{Si}_{6}$ phase was distinguished from the $\beta-\mathrm{Al}_{5} \mathrm{FeSi}$ phase by containing a significantly higher magnesium content, while the $\mathrm{Mg}_{2} \mathrm{Si}$ is the darkest script-like phase observed in the optical and SEM micrographs, as seen in Figures 4(a) and 6(a). For both unquenched and quenched unmodified alloys the average composition of the plate-like iron-rich phase detected in the microstructures was within the range of compositions suggested in the literature for the $\beta-\mathrm{Al}_{5} \mathrm{FeSi}$ phase. ${ }^{[48]}$ Therefore, the plate-like iron-rich phase observed on unquenched and quenched unmodified alloys is most likely $\beta-\mathrm{Al}_{5} \mathrm{FeSi}$. The script-like iron-rich phase in both unquenched and quenched unmodified alloys have significantly less iron and more magnesium and silicon compared to the plate-like iron-rich phase in the same alloys, as seen in Table IV and Figures 5(a) through (d). The constitutions $\mathrm{Al}_{11} \mathrm{FeMg}_{3} \mathrm{Si}_{5}$ and $\mathrm{Al}_{12} \mathrm{FeMg}_{4} \mathrm{Si}_{4}$ were calculated for the script-like iron-rich phase using the compositions 


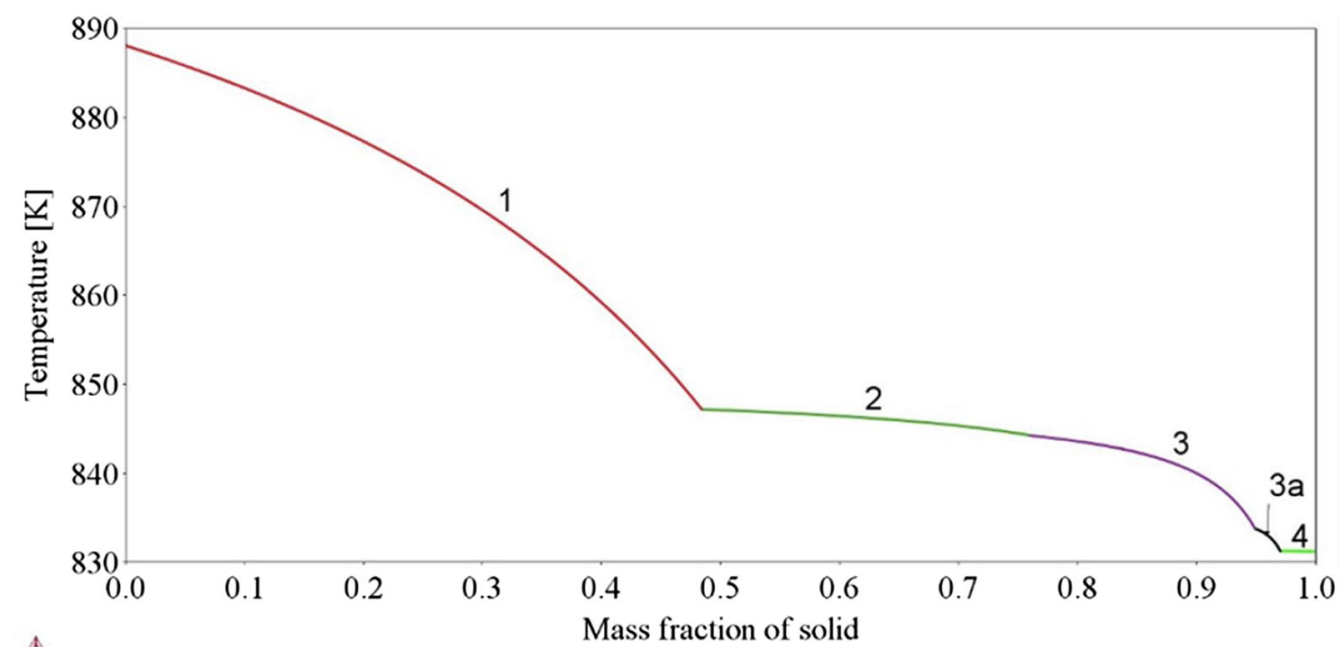

(a)

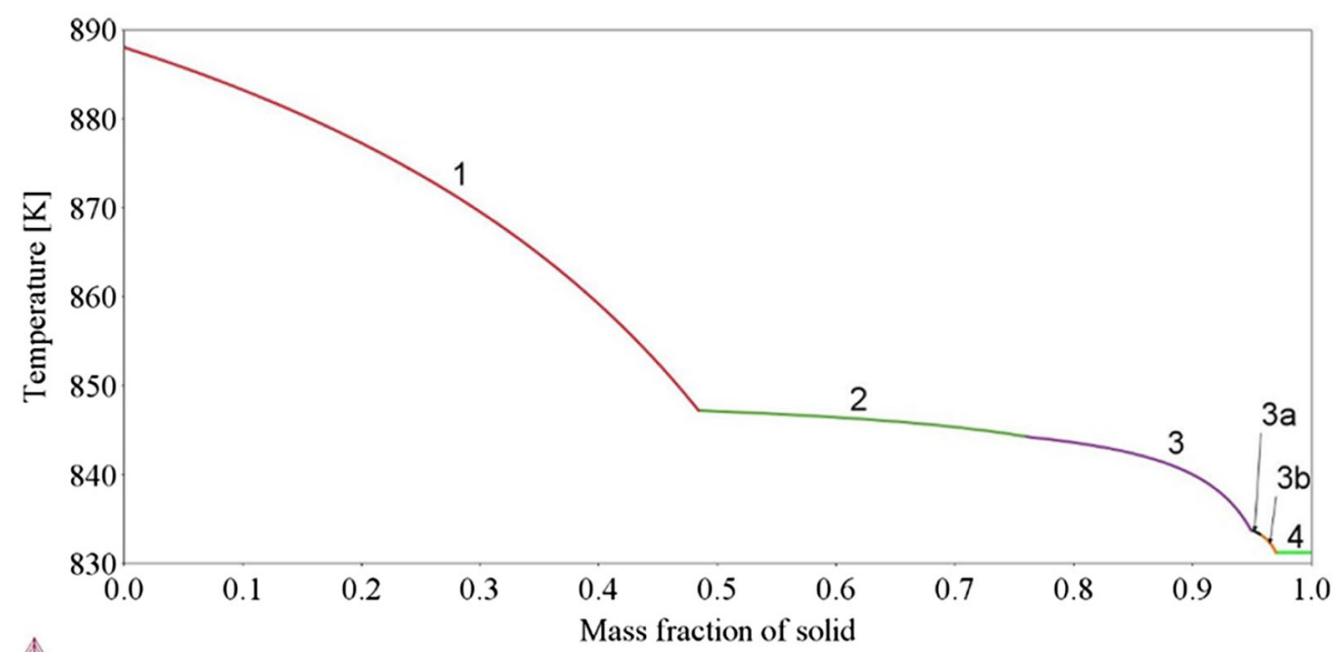

(b)

Fig. 3 - Solidification paths calculated by Thermocalc ${ }^{\top \mathrm{M}}$ using the Scheil-Gulliver model for an Al-7Si-0.3Mg- $0.2 \mathrm{Fe}(a)$ without strontium and $(b)$ with $250 \mathrm{ppm}$ of strontium. $1-\alpha$-Al + liquid; $2-\alpha$-Al + eutectic silicon + liquid; $3-\alpha$-Al + eutectic silicon $+\beta$ - $\mathrm{Al}_{5} \mathrm{FeSi}+$ liquid; $3 \mathrm{a}-\alpha$ - $\mathrm{Al}$ + eutectic silicon $+\beta-\mathrm{Al}_{5} \mathrm{FeSi}+\pi-\mathrm{Al}_{8} \mathrm{FeMg}_{3} \mathrm{Si}_{6}+$ liquid; $3 \mathrm{~b}-\alpha$-Al + eutectic silicon $+\pi-\mathrm{Al}_{8} \mathrm{FeMg}_{3} \mathrm{Si}_{6}+$ liquid; $4-\alpha$-Al + eutectic silicon $+\pi-\mathrm{Al}_{8} \mathrm{FeMg}_{3} \mathrm{Si}_{6}+\mathrm{Mg}_{2} \mathrm{Si}+$ liquid (Color figure online).

listed in Table IV for the unquenched and quenched alloys, respectively. The iron-rich phase with the closest constitution to these formed during solidification of Al-7 $\mathrm{Si}-\mathrm{Mg}$ alloys predicted by Thermocalc ${ }^{\mathrm{TM}}$ is $\pi-\mathrm{Al}_{8} \mathrm{FeMg}_{3} \mathrm{Si}_{6} .{ }^{[27,39]}$ Consequently, it is reasonable to assume that the script-like iron-rich phase is $\pi-\mathrm{Al}_{8} \mathrm{FeMg}_{3} \mathrm{Si}_{6}$ and the different constitutions obtained most likely resulted from the larger size of the interaction volume of X-rays compared to the iron-rich phase volume. In the strontium-modified alloy quenched before the start of the $\mathrm{Al}-\mathrm{Si}$ eutectic reaction the plate-like iron-rich phase has a composition that is similar to the script-like phase in the unquenched and quenched unmodified alloys, as seen in Table IV. Therefore, the plate-like iron-rich phase detected in the strontium modified alloy quenched before the start of the Al-Si eutectic reaction is most likely $\pi-\mathrm{Al}_{8} \mathrm{FeMg}_{3} \mathrm{Si}_{6}$ phase as no other iron-rich phase containing magnesium forms during solidification of Al-7Si-Mg alloys. ${ }^{[10,27,31,39]}$
Figures 4(a) and (b) show microstructures of the unquenched unmodified and strontium-modified alloys. The microstructure of the unquenched unmodified alloy consists of $\alpha$-Al dendrites, coarse flake-like eutectic silicon, plate-like $\beta-\mathrm{Al}_{5} \mathrm{FeSi}$, script-like $\pi-\mathrm{Al}_{8} \mathrm{FeMg}_{3} \mathrm{Si}_{6}$ and $\mathrm{Mg}_{2} \mathrm{Si}$ phases as shown in Figures 4(a) and 5(a) through (d). The $\beta-\mathrm{Al}_{5} \mathrm{FeSi}$ phase was commonly found close to eutectic silicon which suggests that the $\beta-\mathrm{Al}_{5} \mathrm{FeSi}$ phase formed in the ternary eutectic reaction $\mathrm{L} \rightarrow \mathrm{Al}+\mathrm{Si}+\beta-\mathrm{Al}_{5} \mathrm{FeSi}$, as proposed in the literature for $\mathrm{Al}-\mathrm{Si}$ alloys with similar iron contents. ${ }^{[27,39,49]}$ Additionally, Thermocalc ${ }^{\mathrm{TM}}$ calculations predict the formation of $\beta-\mathrm{Al}_{5} \mathrm{FeSi}$ by the ternary eutectic reaction, as shown in Figure 3. The $\pi-\mathrm{Al}_{8} \mathrm{FeMg}_{3} \mathrm{Si}_{6}$ phase is frequently found growing on $\beta-\mathrm{Al}_{5} \mathrm{FeSi}$ platelets in the unquenched samples, as shown in Figures 4(a) and (b). This quaternary phase can form by two different reactions during solidification ${ }^{[27,39,49]}$; peritectic reaction $\mathrm{L}+\beta-\mathrm{Al}_{5} \mathrm{FeSi} \rightarrow \mathrm{Al}+\mathrm{Si}+\pi-\mathrm{Al}_{8} \mathrm{FeMg}_{3} \mathrm{Si}_{6}$ and quaternary reaction $\mathrm{L} \rightarrow \mathrm{Al}+\mathrm{Si}+\pi-\mathrm{Al}_{8} \mathrm{FeMg}_{3} \mathrm{Si}_{6}+$ 


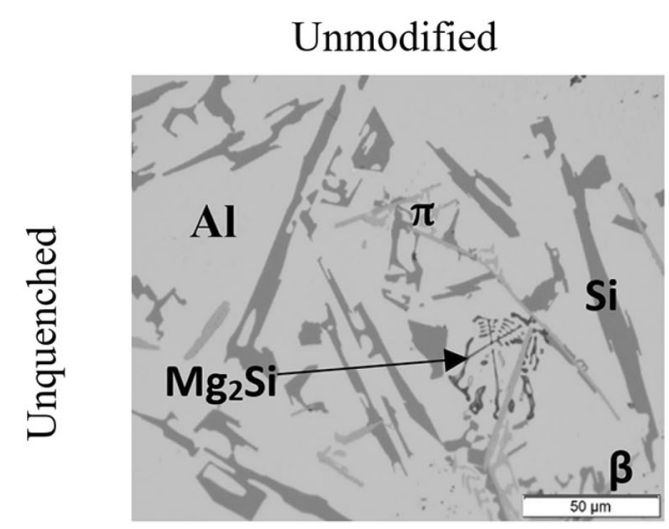

(a)

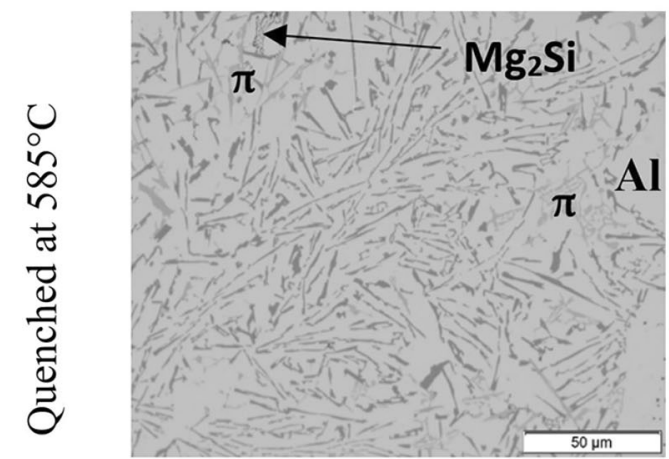

(c)

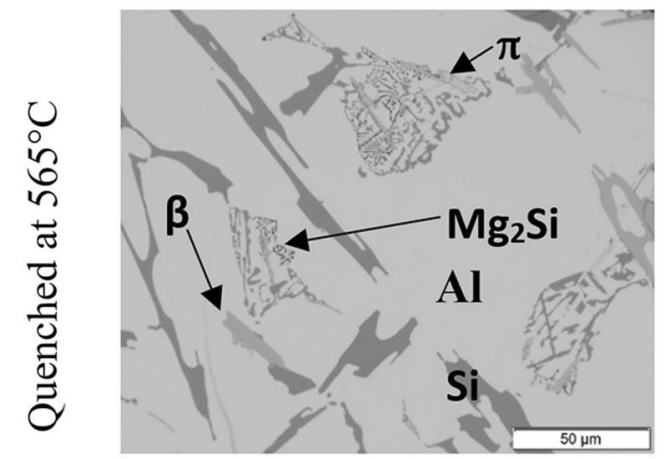

(e)

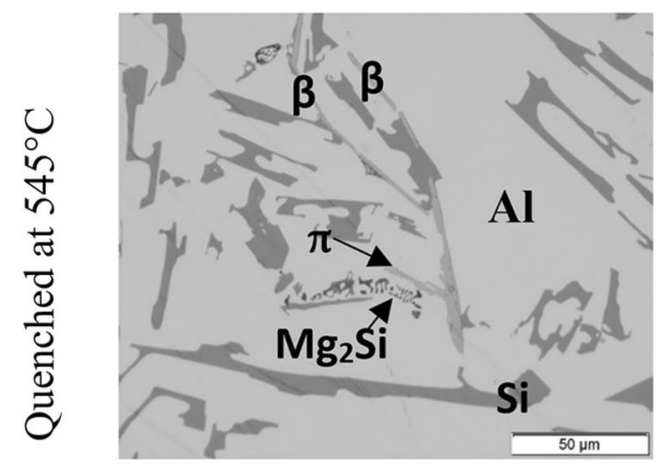

(g)

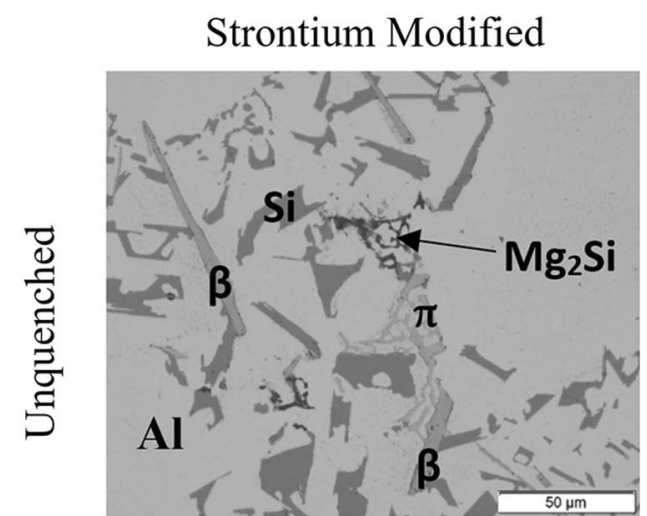

(b)

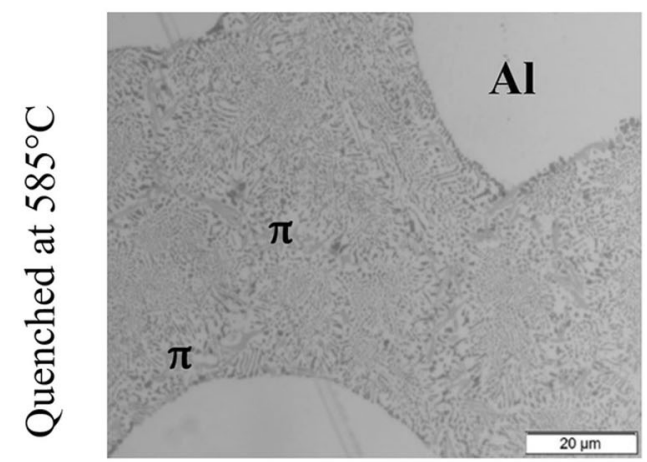

(d)

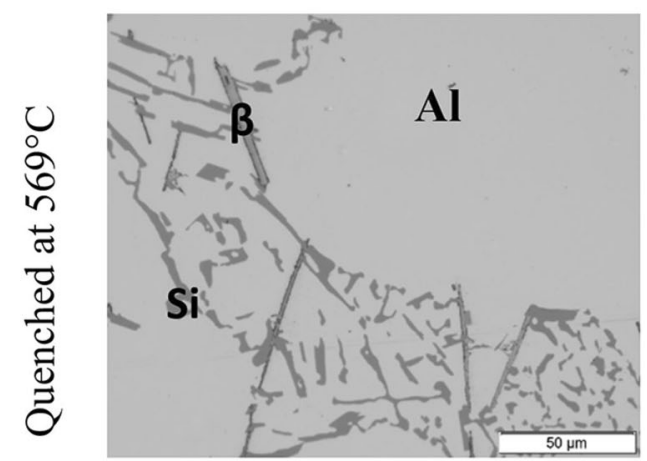

(f)

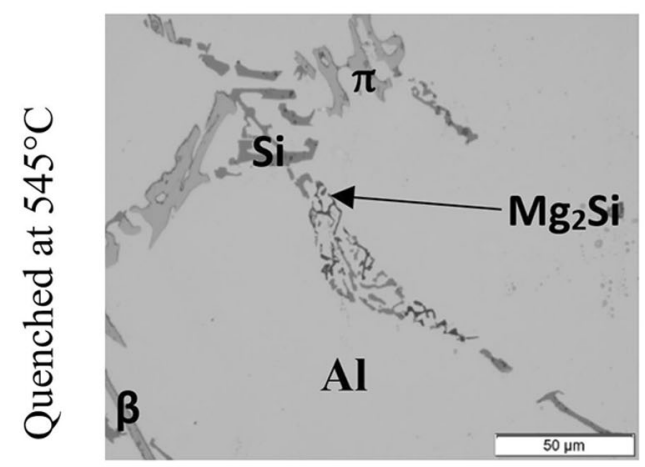

(h)

Fig. 4 - Optical micrographs of unmodified and strontium-modified Al-7Si-0.3Mg-0.2Fe alloys: $(a)$ and $(b)$ unquenched samples, $(c)$ and $(d)$ quenched at $858 \mathrm{~K}\left(585^{\circ} \mathrm{C}\right)$ (before the start of the $\mathrm{Al}-\mathrm{Si}$ eutectic reaction), $(e)$ and $(f)$ quenched at $838 \mathrm{~K}\left(565{ }^{\circ} \mathrm{C}\right)$ and $842 \mathrm{~K}\left(569{ }^{\circ} \mathrm{C}\right)$, respectively, and $(g)$ and $(h)$ quenched at $818 \mathrm{~K}\left(545^{\circ} \mathrm{C}\right)$ (after end of solidification). 


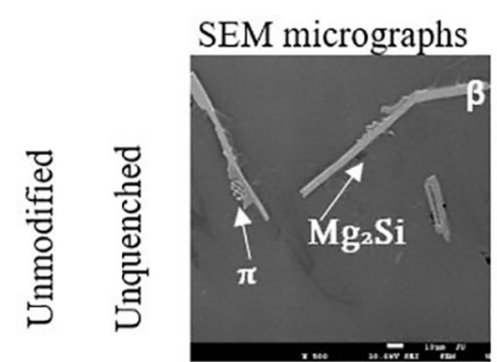

(a)

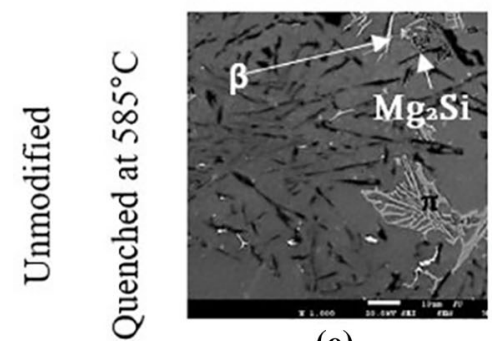

(e)

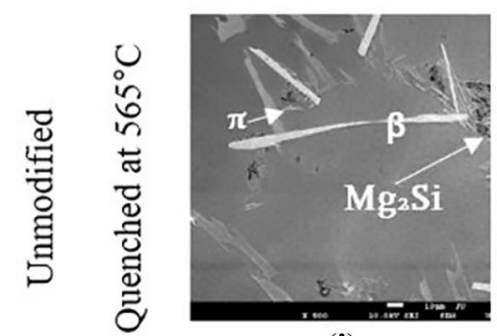

(i)

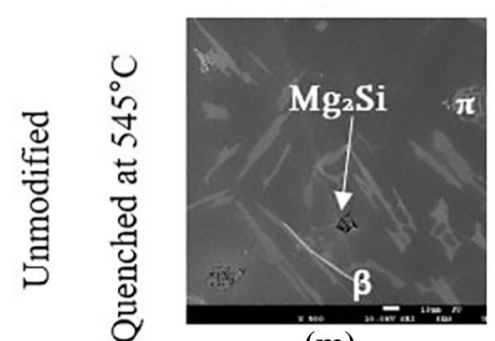

(m)

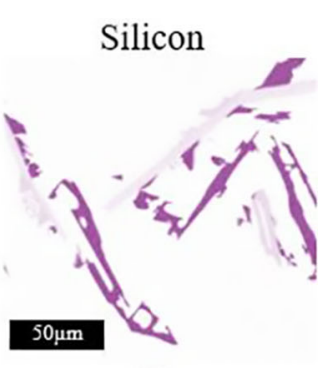

(b)

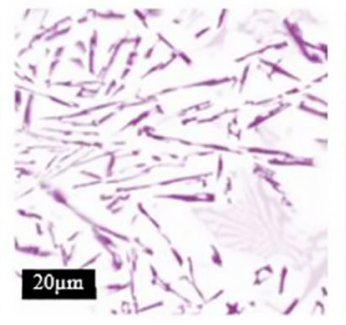

(f)

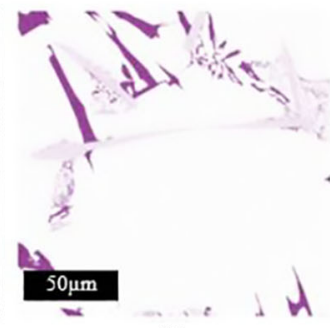

(j)

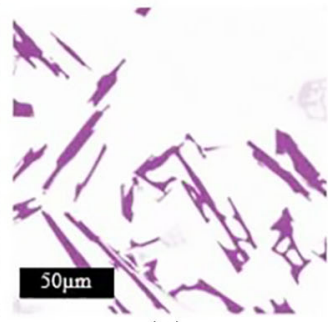

(n)
Magnesium

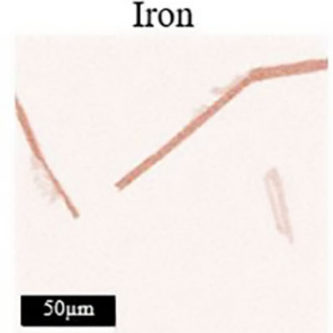

(d) (c)

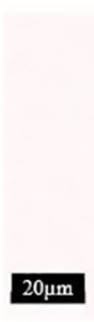

$50 \mu \mathrm{m}$

(g)
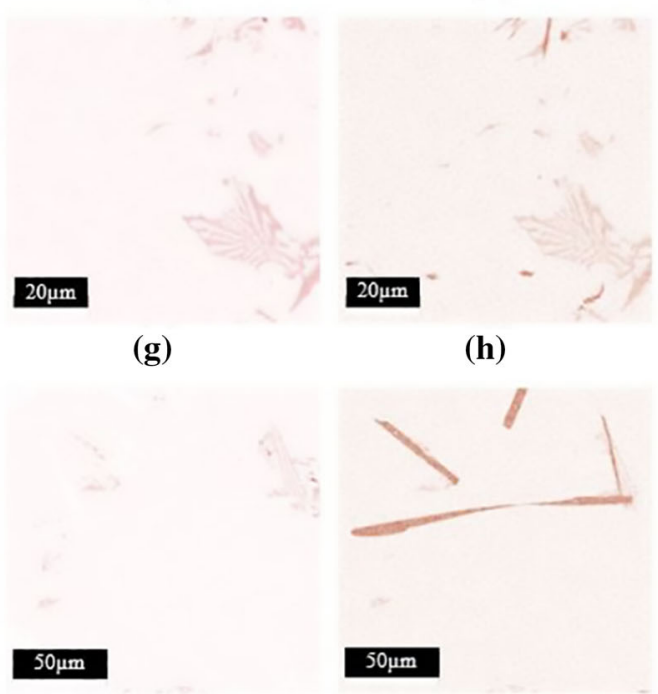

(k)

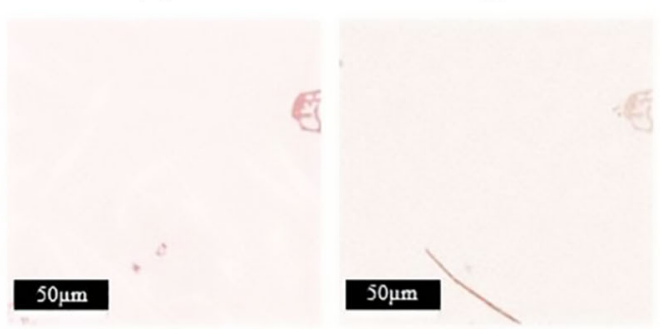

(o)

(p)

Fig. 5- SEM micrographs and corresponding EDS maps showing silicon, magnesium and iron distribution in the thermal analysis and quenched unmodified alloy samples: $\left(a\right.$ to $d$ ) unqueched sample, $(e$ to $h)$ quenched at $858 \mathrm{~K}\left(585^{\circ} \mathrm{C}\right)$ (before the start of the Al-Si eutectic reaction), $(i$ to $l)$ quenched at $838 \mathrm{~K}\left(565{ }^{\circ} \mathrm{C}\right)$ and $(m$ to $p)$ quenched at $818 \mathrm{~K}\left(545^{\circ} \mathrm{C}\right)$ (Color figure online).

$\mathrm{Mg}_{2} \mathrm{Si}$. The peritectic reaction $\mathrm{L}+\beta-\mathrm{Al}_{5} \mathrm{FeSi} \rightarrow \mathrm{Al}+$ $\mathrm{Si}+\pi-\mathrm{Al}_{8} \mathrm{FeMg}_{3} \mathrm{Si}_{6}$ involves solid-state diffusion which reduces the reaction rate to such an extent that no thermal trace is produced in thermal analysis. ${ }^{[27,49]}$ It is possible that the peritectic reaction occurred in the unquenched samples that were allowed to cool slowly until the end of solidification. However, the $\pi-\mathrm{Al}_{8} \mathrm{FeMg}_{3} \mathrm{Si}_{6}$ phase most likely resulted from the quaternary reaction due to the close association with $\mathrm{Mg}_{2} \mathrm{Si}$ in the microstructure, as seen in Figure 4(b), and the thermal traces observed on thermal analysis. The unquenched strontium modified alloy in this work contained finer eutectic silicon flakes compared to the unmodified alloy, but not a fully modified fibrous eutectic, as seen in Figure 4(b). In the less modified eutectic regions of the unquenched strontium modified alloy, larger $\beta-\mathrm{Al}_{5} \mathrm{FeSi}$ and $\pi-\mathrm{Al}_{8} \mathrm{FeMg}_{3} \mathrm{Si}_{6}$ phases were obtained compared to the unquenched unmodified alloy, as seen in Figure 4. Figure 7 shows the average length of the iron-rich intermetallics in the different samples. Smaller $\beta-\mathrm{Al}_{5} \mathrm{FeSi}$ and $\pi-\mathrm{Al}_{8} \mathrm{FeMg}_{3} \mathrm{Si}_{6}$ phases are observed in the unquenched unmodified alloy compared to the unquenched strontium-modified alloy. Similar results were obtained in other studies where larger $\beta-\mathrm{Al}_{5} \mathrm{FeSi}^{[23]}$ and $\pi-\mathrm{Al}_{8} \mathrm{FeMg}_{3} \mathrm{Si}_{6}$ phases ${ }^{[36]}$ were observed with the addition of strontium in Al-Si alloys.

Figures 4(c) and (d) show microstructures of the unmodified and strontium modified alloys quenched before the start of the Al-Si eutectic reaction. The cooling rate generated during the eutectic reaction in these samples is much higher compared to that existing in the unquenched alloys. Smaller script-like $\pi-\mathrm{Al}_{8} \mathrm{FeMg}_{3} \mathrm{Si}_{6}$ was obtained in the samples quenched before the start of the $\mathrm{Al}-\mathrm{Si}$ eutectic reaction, as seen in 


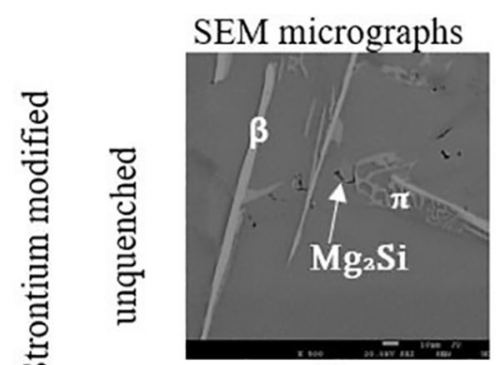

(a)

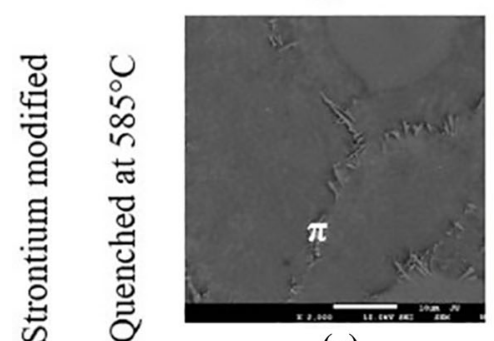

(e)

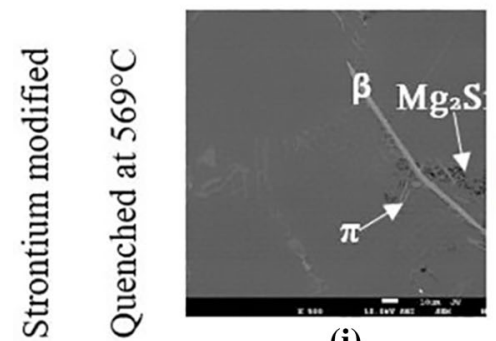

(i)

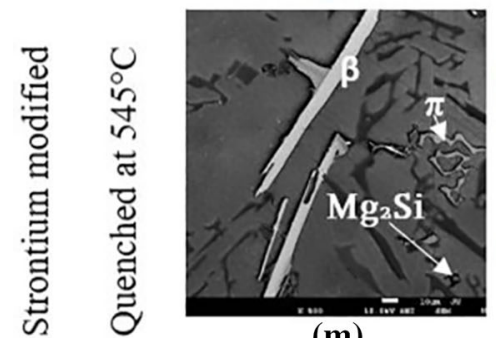

(m)

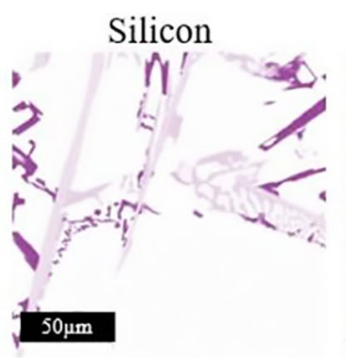

(b)

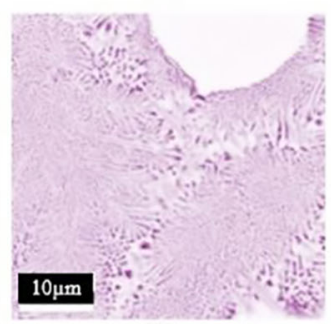

(f)

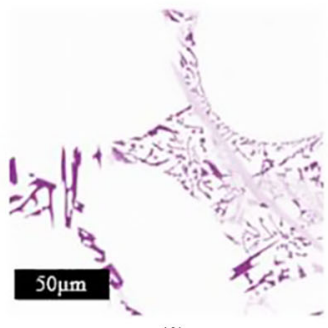

(j)

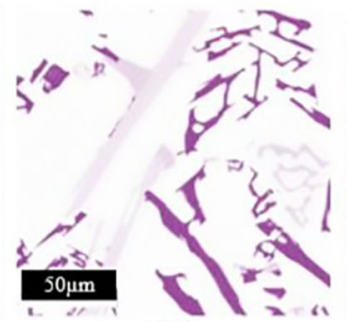

(n)

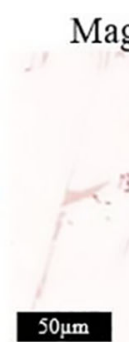

(c)

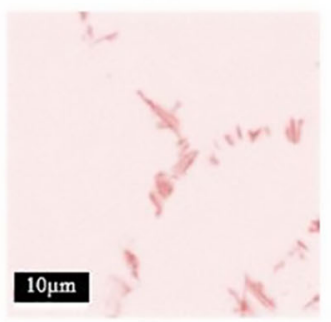

(g)

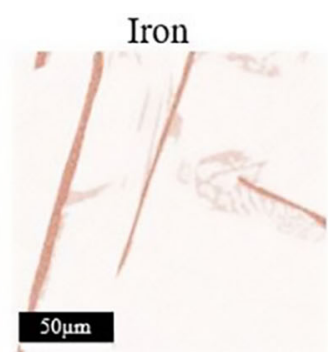

(d)

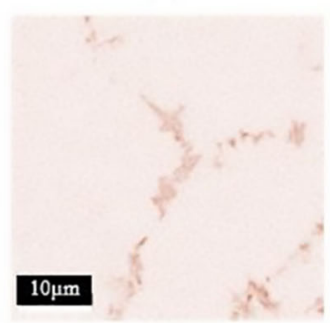

(h)
$50 \mu \mathrm{m}$

(k)

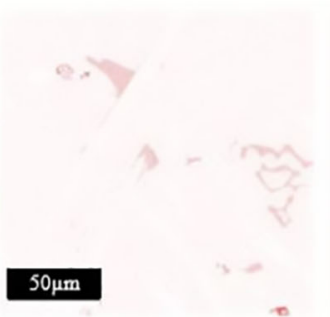

(o)

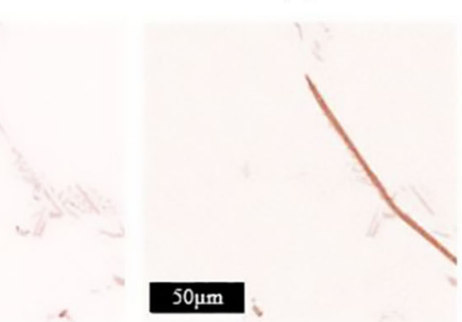

(I)

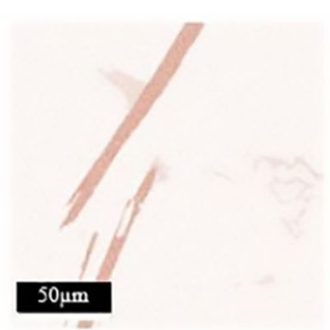

(p)

Fig. 6 - SEM micrographs and corresponding EDS maps showing silicon, magnesium and iron distribution in the thermal analysis and quenched strontium-modified alloy samples: $(a$ to $d)$ unqueched sample, $(e$ to $h)$ quenched at $858 \mathrm{~K}\left(585^{\circ} \mathrm{C}\right)$ (before the start of the $\mathrm{Al}-\mathrm{Si}$ eutectic reaction), $(i$ to $l)$ quenched at $842 \mathrm{~K}\left(569^{\circ} \mathrm{C}\right)$ and $(m$ to $p)$ quenched at $818 \mathrm{~K}\left(545^{\circ} \mathrm{C}\right)$ (Color figure online).

Table IV. Average Composition of the Different Iron-Rich Intermetallic Phases. Compositions in Weight Percent

\begin{tabular}{|c|c|c|c|c|c|}
\hline Alloy & Suggested Phase & $\mathrm{Al}$ & $\mathrm{Fe}$ & $\mathrm{Mg}$ & $\mathrm{Si}$ \\
\hline \multirow[t]{2}{*}{ Unmodified-Unquenched } & plate-like $\beta-\mathrm{Al}_{5} \mathrm{FeSi}$ & $54.4 \pm 2.4$ & $28.8 \pm 3.9$ & $1.3 \pm 0.2$ & $15.5 \pm 1.8$ \\
\hline & script-like $\pi-\mathrm{Al}_{8} \mathrm{FeMg}_{3} \mathrm{Si}_{6}$ & $48.4 \pm 8.4$ & $10.3 \pm 2.3$ & $17.6 \pm 4.7$ & $23.7 \pm 2.9$ \\
\hline \multirow[t]{2}{*}{ Unmodified-Quenched at $858 \mathrm{~K}\left(585^{\circ} \mathrm{C}\right)$} & plate-like $\beta-\mathrm{Al}_{5} \mathrm{FeSi}$ & $55.9 \pm 6.7$ & $30.7 \pm 1.4$ & $1.4 \pm 0.6$ & $12.0 \pm 6.4$ \\
\hline & script-like $\pi-\mathrm{Al}_{8} \mathrm{FeMg}_{3} \mathrm{Si}_{6}$ & $53.5 \pm 5.6$ & $9.6 \pm 1.2$ & $15.5 \pm 2.3$ & $21.3 \pm 2.2$ \\
\hline Strontium modified-Quenched at $858 \mathrm{~K}\left(585^{\circ} \mathrm{C}\right)$ & plate-like $\pi$ - $\mathrm{Al}_{8} \mathrm{FeMg} \mathrm{Si}_{6}$ & $61.6 \pm 6.9$ & $8.8 \pm 2.0$ & $11.7 \pm 2.3$ & $18.0 \pm 3.3$ \\
\hline SSM Al-7Si-0.3Mg-T5 & plate-like $\pi-\mathrm{Al}_{8} \mathrm{FeMg}_{3} \mathrm{Si}_{6}$ & $63.9 \pm 5.0$ & $6.2 \pm 1.7$ & $10.8 \pm 1.9$ & $19.0 \pm 2.6$ \\
\hline SSM Al-7Si-0.3Mg-T6 & plate-like $\beta-\mathrm{Al}_{5} \mathrm{FeSi}$ & $70.2 \pm 5.0$ & $16.9 \pm 3.6$ & $1.7 \pm 0.2$ & $11.2 \pm 4.2$ \\
\hline
\end{tabular}

Figure 7(a). Additionally, $\pi-\mathrm{Al}_{8} \mathrm{FeMg}_{3} \mathrm{Si}_{6}$ was the only intermetallic phase detected in the strontium modified alloy quenched before the start of the Al-Si eutectic reaction, as seen in Figures 6(e) through (h). However, in the unmodified alloy quenched before the start of the
$\mathrm{Al}-\mathrm{Si}$ eutectic reaction, both $\beta-\mathrm{Al}_{5} \mathrm{FeSi}$ and $\pi-\mathrm{Al}_{8} \mathrm{FeMg}_{3} \mathrm{Si}_{6}$ were observed, as shown in Figures 5(e) through (h). Figure 8 shows the area fraction of the different intermetallic phases detected in the selected samples. Lower fraction of $\beta-\mathrm{Al}_{5} \mathrm{FeSi}$ and $\mathrm{Mg}_{2} \mathrm{Si}$ phases 


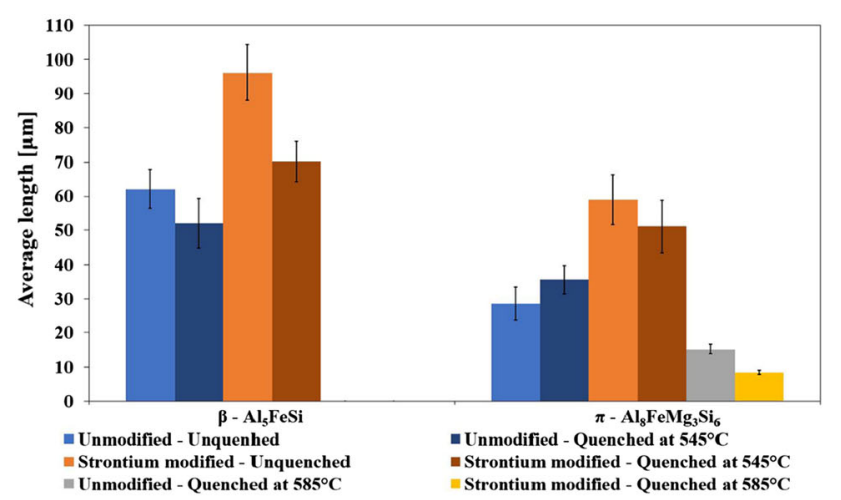

(a)

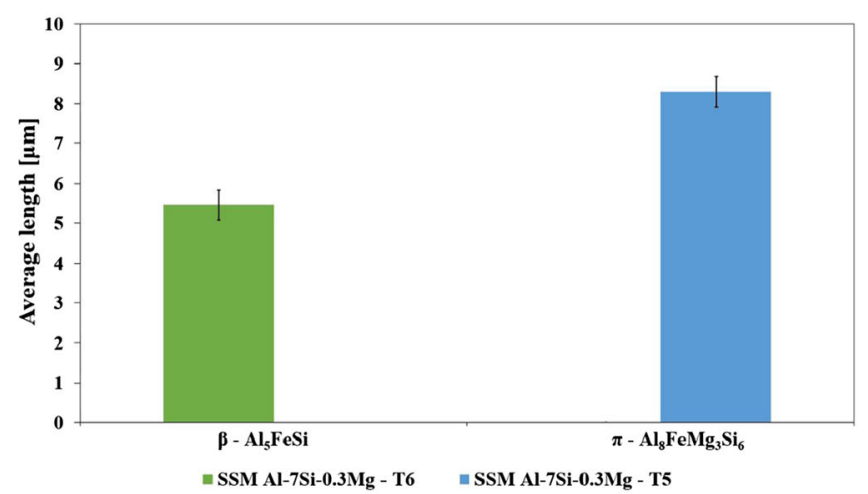

(b)

Fig. 7-Average length of $\beta-\mathrm{Al}_{5} \mathrm{FeSi}$ and $\pi-\mathrm{Al}_{8} \mathrm{FeMg}_{3} \mathrm{Si}_{6}$ phases in $(a)$ unquenched and quenched alloys and $(b)$ SSM castings. In samples which an iron-rich intermetallic phase was not detected or appeared mostly bounded by other phase the average length of that phase is not shown (Color figure online).

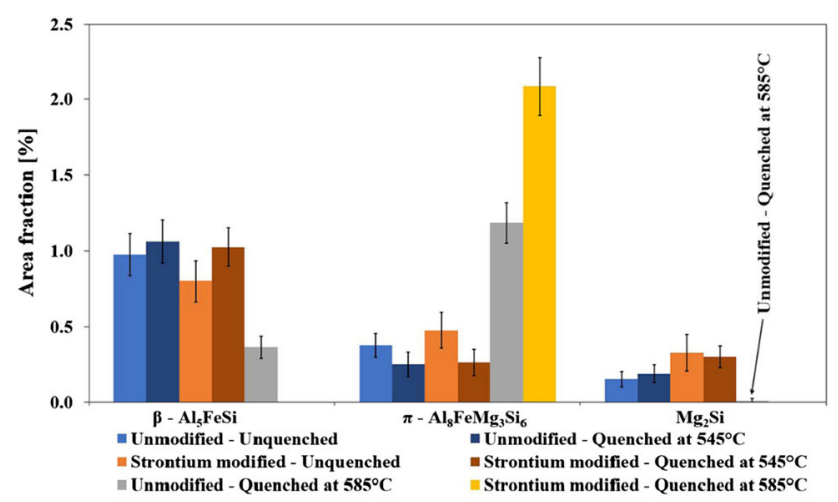

(a)

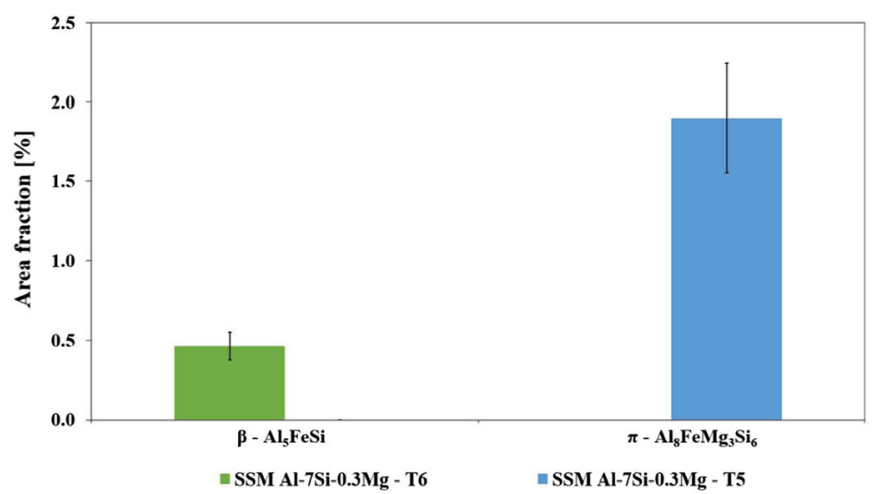

(b)

Fig. 8- Area fraction of intermetallic phases in (a) unquenched and quenched alloys and (b) SSM castings (Color figure online).

were obtained in the quenched unmodified alloy in addition to a refinement of the eutectic silicon flakes compared to the unquenched unmodified alloy, as seen in Figure 8(a). Additionally, larger $\beta-\mathrm{Al}_{5} \mathrm{FeSi}$ phase was observed in the unquenched unmodified alloy compared to the unmodified alloy quenched before the start of the $\mathrm{Al}-\mathrm{Si}$ eutectic reaction, as seen in Figures 4(c), 5(e) through (h) and 7(a). The addition of strontium to the alloy quenched before the start of the Al-Si eutectic reaction resulted in a change of the eutectic silicon morphology from refined flakes to fibrous as seen in Figure 4(d). Needle-like and script-like morphologies (observed in two dimensions) were obtained for the $\pi-\mathrm{Al}_{8} \mathrm{FeMg}_{3} \mathrm{Si}_{6}$ phase in the unmodified and strontium modified alloys quenched before the start of the Al-Si eutectic reaction, respectively. The addition of strontium to the alloy quenched before the start of the Al-Si reaction resulted in a decrease in size of the intermetallic phases compared to the unmodified alloy, as shown in Figure 7(a). Yu et al. ${ }^{[16]}$ also observed a change in morphology of intermetallic phases from script-like to needle-like with strontium addition to an Al-10Si-0.3Fe alloy. In the strontium-modified alloy, the $\pi-\mathrm{Al}_{8} \mathrm{FeMg}_{3} \mathrm{Si}_{6}$ phase is located at the eutectic cell boundaries, as shown in Figures 4(d) and 6(e), while this phase is dispersed in the eutectic regions in the unmodified alloy. The $\pi-\mathrm{Al}_{8} \mathrm{FeMg}_{3} \mathrm{Si}_{6}$ phase is the main iron-rich phase containing magnesium that forms in Al-7Si-Mg alloys. ${ }^{[10,27,31,47}$ A similar change in morphology of the $\pi-\mathrm{Al}_{8} \mathrm{FeMg}_{3} \mathrm{Si}_{6}$ phase from script-like to plate-like caused by the addition of strontium to an Al-15Si-14Mg-4Cu was reported. ${ }^{[50]}$ Therefore, the plate-like iron-rich phase containing magnesium detected in the strontium modified alloy is likely $\pi-\mathrm{Al}_{8} \mathrm{FeMg}_{3} \mathrm{Si}_{6}$ phase. The composition of the plate-like phase formed in the strontium modified alloy quenched before the start of the Al-Si eutectic reaction (Table IV) results in the constitution $\mathrm{Al}_{14} \mathrm{FeMg}_{3} \mathrm{Si}_{4}$ which differs from the $\pi-\mathrm{Al}_{8} \mathrm{FeMg}_{3} \mathrm{Si}_{6}$. This difference is most likely caused by the larger size of the X-ray interaction volume compared to the volume of the iron-rich intermetallic phase.

Figure 4(e) shows the microstructure of the unmodified alloy which was quenched just after the beginning of the eutectic arrest. Figure 4(f) shows the microstructure of the strontium modified alloy which was quenched halfway along the eutectic arrest. In both unmodified and strontium modified alloys which were quenched along the eutectic arrest, two different eutectic microstructures were observed; a coarse eutectic 
microstructure that solidified before quenching and a fine eutectic microstructure that formed during quenching. For both alloys the coarse and fine eutectic microstructures were similar to that obtained in the unquenched and samples quenched before the start of the Al-Si eutectic reaction, respectively. Similar to other studies, ${ }^{[21]}$ strontium-rich intermetallics were observed in the modified alloy quenched halfway along eutectic arrest and quenched before the start of the Al-Si eutectic reaction, as shown in Figure 9. In the alloy quenched midway along the eutectic arrest, the strontium-rich intermetallics were just observed in the finer eutectic regions that formed during quenching, as seen in Figure 9(b).

Figures $4(\mathrm{~g})$ and $(\mathrm{h})$ show representative microstructures of the unmodified and modified alloys quenched after the end of solidification. These samples display very similar microstructures to those obtained in the unquenched alloys. Additionally, no significant differences in area fraction of $\mathrm{Mg}_{2} \mathrm{Si}$ phase was found for the unmodified and modified alloys quenched after the end of solidification compared to the unquenched alloys. The area fraction of $\pi-\mathrm{Al}_{8} \mathrm{FeMg}_{3} \mathrm{Si}_{6}$ tends to be slightly smaller for the unmodified and modified alloys quenched after the end of solidification compared to the unquenched alloys. However, the differences are very small and it is reasonable to assume that no significant dissolution of intermetallic phases containing magnesium occurs during solid-state cooling of the unquenched alloys.

\section{SSM Al-7Si-0.3Mg Castings}

Figure 10 shows representative microstructures of the SSM Al-7Si-0.3Mg castings in the as-cast, T5 and T6 conditions. The microstructure of the SSM casting in the T5 condition consists of primary $\alpha$-Al globules, modified Al-Si eutectic and a minor fraction of intermetallic phases in the eutectic regions, as shown in Figures 10(b) and (c). Similar to the strontium modified alloy quenched before the start of eutectic reaction
(Figure 6(e)), the intermetallic phases in the SSM microstructure are located at the eutectic cell boundaries and no $\mathrm{Mg}_{2} \mathrm{Si}$ intermetallics was observed in as-cast and T5 conditions. Similar microstructure was obtained for the SSM casting in the as-cast condition, as seen in Figure 10(a). The microstructure of SSM Al-7Si-0.3Mg in the T6 condition consisted of primary $\alpha$-Al globules, spheroidized eutectic silicon and a minor fraction of intermetallic phases in the eutectic regions, as shown in Figure 10(d). Smaller intermetallic phases were observed in the SSM Al-7Si-0.3Mg casting in the T6 condition compared to the as-cast and T5 condition, as seen in Figures 7(b) and 10.

EDS composition maps were used to identify the intermetallic phases observed in the microstructures (Figure 10) of SSM castings in both T5 and T6 conditions and the representative areas analyzed are shown in Figure 11. In the SSM Al-7Si-0.3Mg casting in the $\mathrm{T} 5$ condition an iron-rich plate-like phase containing magnesium, likely $\pi-\mathrm{Al}_{8} \mathrm{FeMg}_{3} \mathrm{Si}_{6}$, was observed at the eutectic cell boundaries as shown in Figures 10(a) and (b). Similar result was obtained for the strontium modified A1-7Si-0.3Mg alloy quenched before the start of the Al-Si eutectic reaction, as seen in Figure 4(d) and Table IV.

For the Al-7Si-0.3Mg casting in the T6 condition the intermetallic phase identified was mainly $\beta-\mathrm{Al}_{5} \mathrm{FeSi}$, as the magnesium concentration was lower in the intermetallic phase region compared to the surroundings, as shown in Figures 11(e) through (h). The $\beta$ - $\mathrm{Al}_{5} \mathrm{FeSi}$ phase detected in the SSM Al-7Si-0.3Mg casting in the T6 condition has a high concentration of aluminum that most likely results from the effect of the $\alpha$-Al matrix that surrounds the $\beta-\mathrm{Al}_{5} \mathrm{FeSi}$ phase on the measurements. The smaller size of the $\beta-\mathrm{Al}_{5} \mathrm{FeSi}$ phase in the SSM casting in the T6 condition compared to the same phase in the unmodified and strontium-modified unquenched alloys results in larger interaction of the $\alpha$-Al matrix in the EDS measurements, as shown in Table IV. It seems that the $\pi-\mathrm{Al}_{8} \mathrm{FeMg}_{3} \mathrm{Si}_{6}$ obtained in the as-cast condition transformed into $\beta-\mathrm{Al}_{5} \mathrm{FeSi}$ during solution

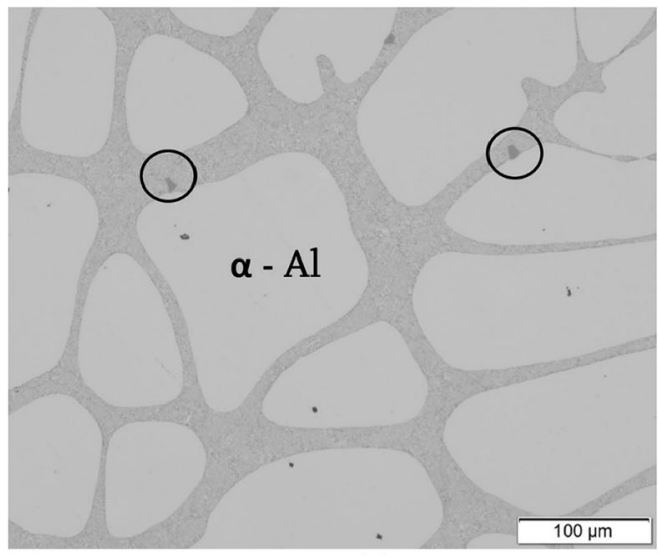

(a)

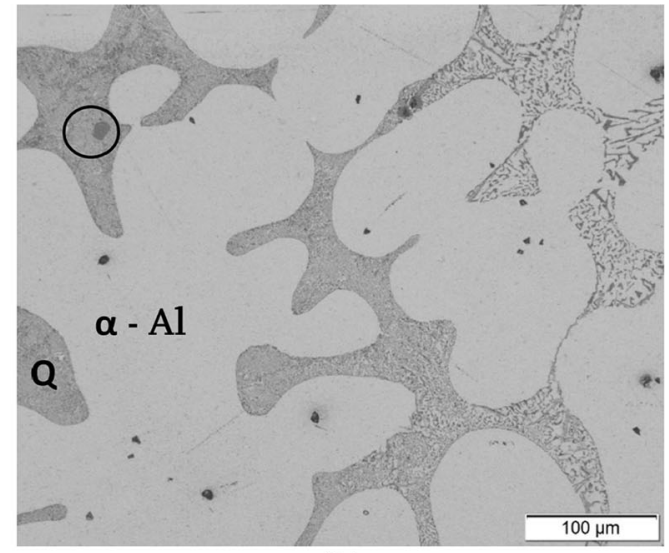

(b)

Fig. 9-Optical micrographs showing strontium-rich intermetallics (highlighted by circles) in strontium-modified alloys (a) quenched at $858 \mathrm{~K}$ $\left(585^{\circ} \mathrm{C}\right.$ ) (before the start of the $\mathrm{Al}-\mathrm{Si}$ eutectic reaction) and $(b)$ quenched at $842 \mathrm{~K}\left(569^{\circ} \mathrm{C}\right)$ (midway along the eutectic reaction). $Q-$ quenched liquid. 


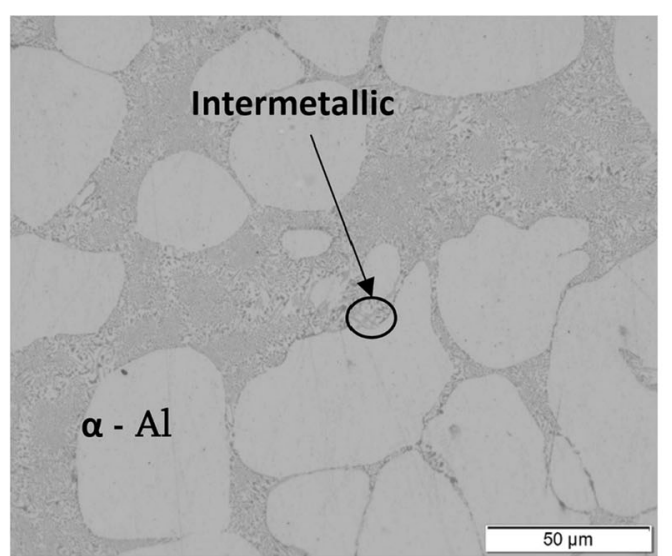

(a)

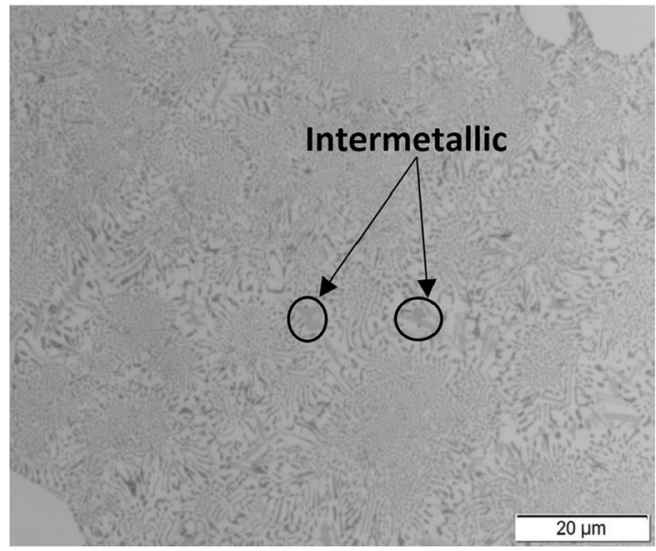

(c)

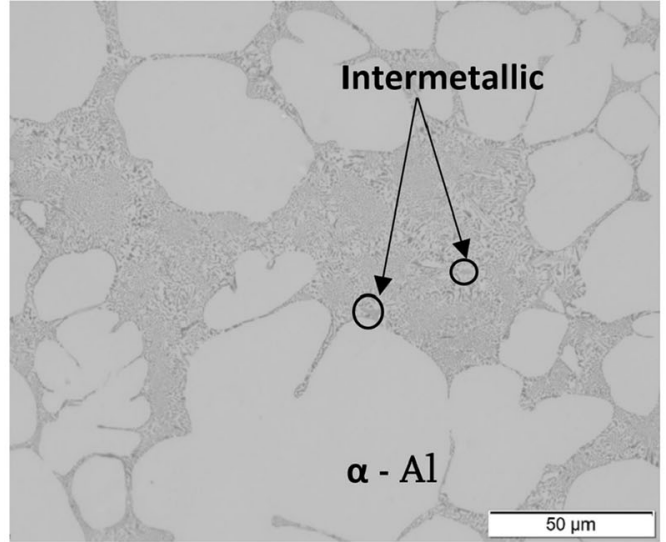

(b)

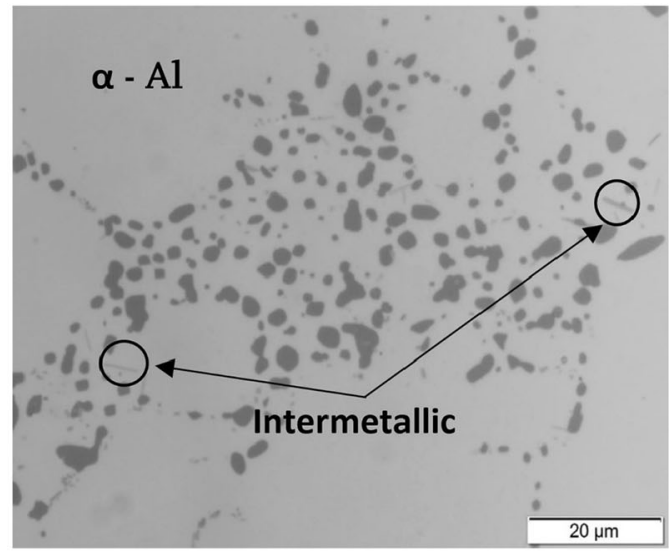

(d)

Fig. 10 - Optical micrographs of SSM Al-7Si-0.3Mg casting in the (a) as-cast, $(b)$ and $(c)$ T5 and $(d)$ T6 conditions. Dark gray-Eutectic silicon. Light gray-iron-rich intermetallics.

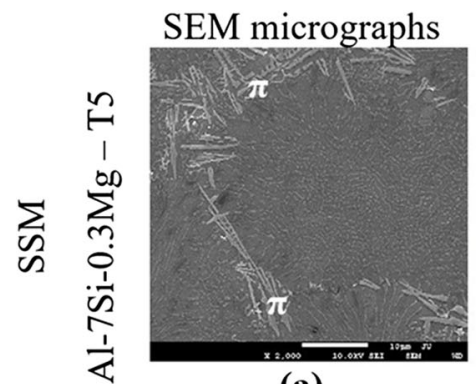

(a)

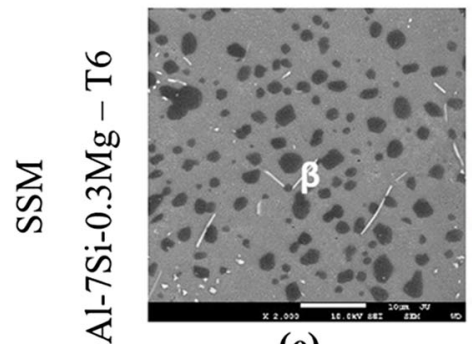

(e)

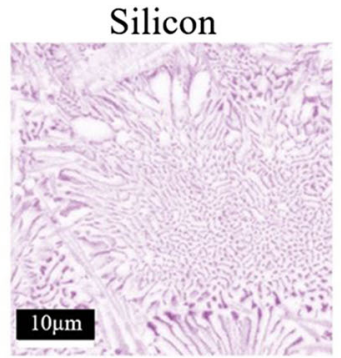

(b)

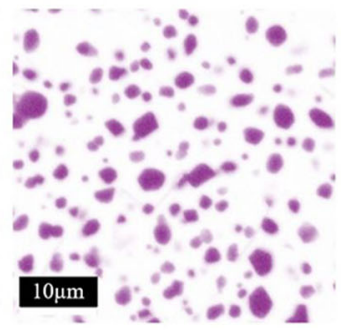

(f)

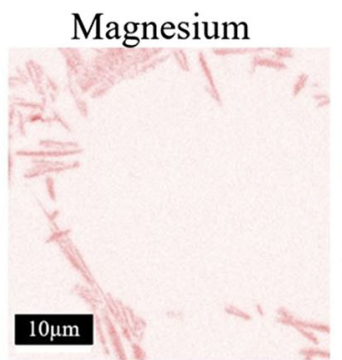

(c)

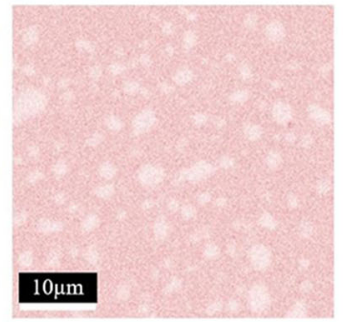

(g)

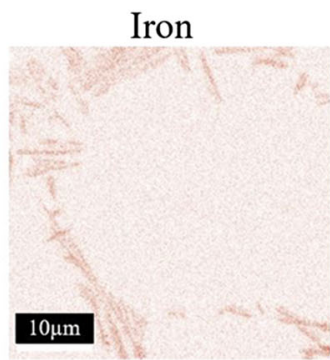

(d)

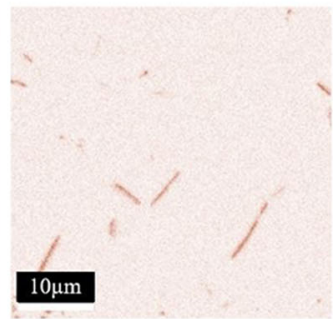

(h)

Fig. 11-SEM micrographs and the respective EDS elemental maps for silicon, magnesium and iron of the SSM Al-7Si-0.3Mg castings in the (a to $d) \mathrm{T} 5$ and ( $e$ to $h) \mathrm{T} 6$ conditions (Color figure online). 
treatment and released magnesium into solid solution, as reported in the literature. ${ }^{[27,31]}$

Figure 12 shows DSC heating curves obtained for the first melting cycle of the SSM Al-7Si-0.3Mg in the T5 and T6 conditions and the second melting cycle for the SSM Al-7Si-0.3Mg in the T5 condition. At the start of the first melting cycle in the DSC, the samples have the SSM microstructure formed by the casting and heat treatment processes, as seen in Figure 10. However, at the start of the second melting cycle the microstructure of the DSC sample was generated from the cooling rate set in the DSC.

Three reaction peaks are observed for the first melting cycle of the SSM Al-7Si- $0.3 \mathrm{Mg}$ alloy in the T5 condition and only two reaction peaks for the same alloy in the T6 condition. The reaction peaks I and II result from the melting of primary $\alpha$-Al and Al-Si eutectic, respectively. The reaction peak identified as III most likely results from the melting of the $\pi-\mathrm{Al}_{8} \mathrm{FeMg}_{3} \mathrm{Si}_{6}$ phase because it was the only intermetallic phase identified in the SSM Al-7Si-0.3 Mg casting in the T5 condition, as seen in Figure 11(a). The reaction peak III is not observed in the DSC curve for the Al-7Si-0.3Mg casting in the T6 condition, which suggest that most of the $\pi-\mathrm{Al}_{8} \mathrm{FeMg}_{3} \mathrm{Si}_{6}$ phase has transformed into $\beta-\mathrm{Al}_{5} \mathrm{FeSi}$ phase and released magnesium into $\alpha$-Al solid solution. An additional small reaction peak (identified as IV in the highlighted region in Figure 12) is observed for the second melting cycle of the SSM Al-7Si- $0.3 \mathrm{Mg}$ casting in the T5 condition and occurs at lower temperature compared to the reaction peak III.

Figure 13(a) shows the microstructure of the T5 heat-treated Al-7Si-0.3 Mg alloy after two melting/cooling cycles in the DSC. $\alpha$-Al dendrites, eutectic silicon flakes and intermetallic phases are observed.
Figure 13(b) shows a SEM micrograph and Figures 13(c) through (e) show EDS maps of the SSM Al-7Si- $0.3 \mathrm{Mg}$ casting in the T5 condition after the second cooling cycle in the DSC. It seems that the $\pi-\mathrm{Al}_{8} \mathrm{FeMg}_{3} \mathrm{Si}_{6}$ phase originally observed in the microstructure of the SSM casting in the T5 condition was replaced by $\beta-\mathrm{Al}_{5} \mathrm{FeSi}$ platelets surrounded by $\pi-\mathrm{Al}_{8} \mathrm{FeMg}_{3} \mathrm{Si}_{6}$ phase and dispersed script-like $\mathrm{Mg}_{2} \mathrm{Si}$ phase during solidification in the DSC. Similar morphology and type of intermetallic phases were also observed in the unmodified and strontium-modified alloys except for the samples quenched before the start of the eutectic reaction.

The comparison of the first and second melting curves for the SSM Al-7Si-0.3Mg casting in the T5 condition shown in Figure 12, indicate that an additional reaction peak IV occurred at lower temperature during the second melting cycle. This reaction peak IV can be assumed to result from the dissolution of $\mathrm{Mg}_{2} \mathrm{Si}$, as it was not observed in the as-cast SSM microstructure (Figures 10(a) and (b)), but observed in the microstructure after the second cooling cycle in the DSC for the same alloy, as shown in Figure 13(a).

\section{DISCUSSION}

\section{A. Formation of Intermetallic Phases in Unquenched Alloys}

The discussion in this section is focused on the unmodified and strontium-modified unquenched alloys that were slowly solidified. In the unmodified Al-7Si-0.3Mg alloy a reaction peak identified as 3 , starting at $842 \mathrm{~K}\left(569{ }^{\circ} \mathrm{C}\right)$, was detected after the start of the Al-Si eutectic thermal arrest, as shown in

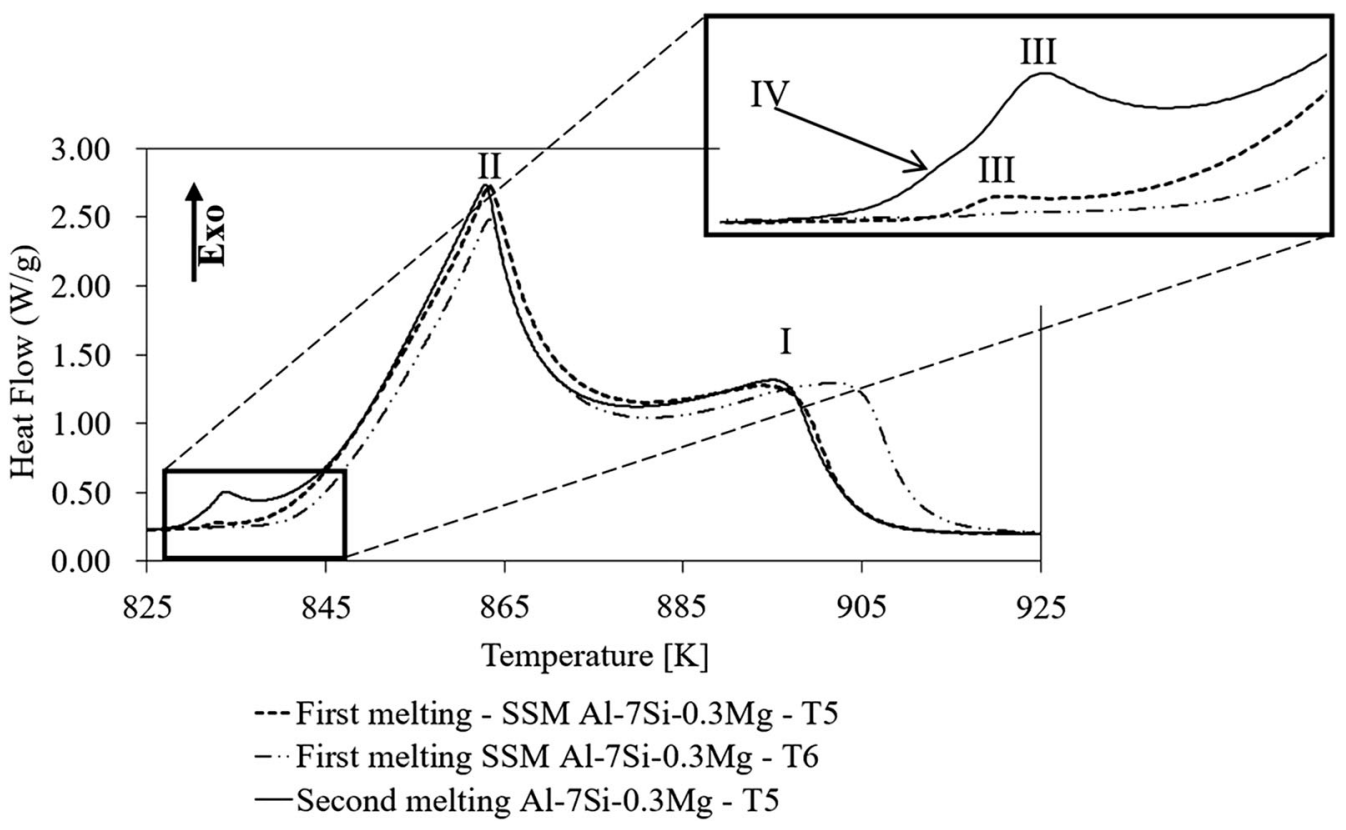

Fig. 12-DSC first melting curves for SSM Al-7Si-0.3Mg casting in the T5 and T6 conditions and second melting curve obtained from the original SSM Al-7Si-0.3Mg casting in the T5 condition. Additional reaction peak that occurs during the second heating cycle is marked by an arrow in the highlighted region. 


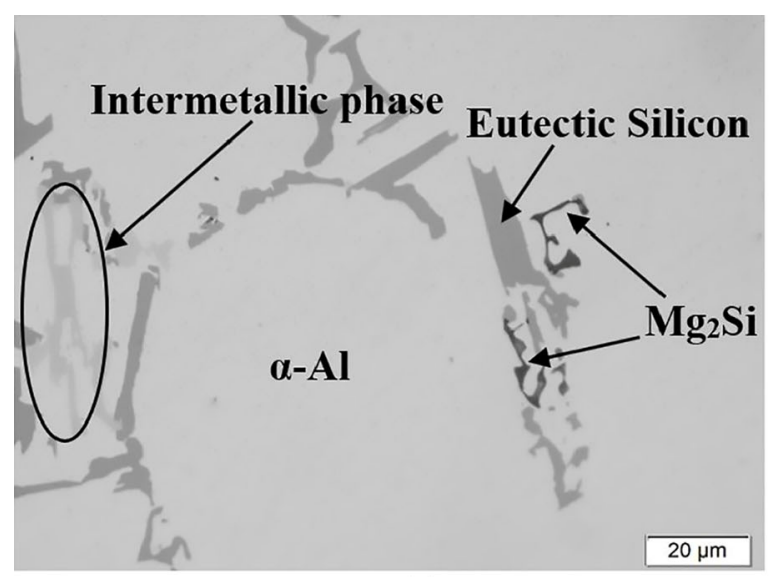

(a)

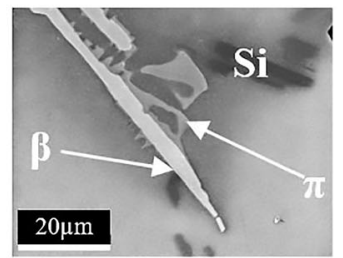

(b)

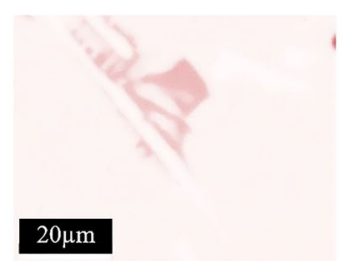

(d)

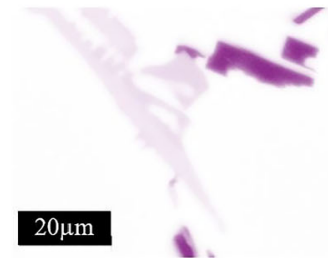

(c)

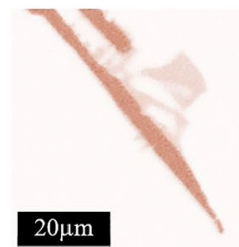

(e)

Fig. 13-SSM Al-7Si-0.3Mg-T5 after second cooling cycle in the DSC. (a) Optical microscopy micrograph. Dark gray—Eutectic silicon. Bright gray - intermetallic phase. Black- $\mathrm{Mg}_{2} \mathrm{Si}(b)$ SEM micrograph. EDS maps showing elements distribution obtained from region in $(b)$; $(c)$ silicon, (d) magnesium and (e) iron (Color figure online).

Figure 2. Two reactions can be associated with the reaction peak 3 observed in the unmodified unquenched alloys; the ternary eutectic reaction $\mathrm{L} \rightarrow \mathrm{Al}+\mathrm{Si}+$ $\beta-\mathrm{Al}_{5} \mathrm{FeSi}$ and the peritectic reaction $\mathrm{L}+\beta-\mathrm{Al}_{5} \mathrm{FeSi} \rightarrow$ $\mathrm{Al}+\mathrm{Si}+\pi-\mathrm{Al}_{8} \mathrm{FeMg}_{3} \mathrm{Si}_{6}$ that occur at $848 \mathrm{~K}\left(575^{\circ} \mathrm{C}\right)$ and $840\left(567{ }^{\circ} \mathrm{C}\right)$, respectively according to Bäckerud et al. ${ }^{[39]}$ The peritectic reaction $\mathrm{L}+\beta-\mathrm{Al}_{5} \mathrm{FeSi} \rightarrow \mathrm{Al}+$ $\mathrm{Si}+\pi-\mathrm{Al}_{8} \mathrm{FeMg}_{3} \mathrm{Si}_{6}$ is unlikely to produce such a thermal arrest in the cooling curve as it progresses slowly because it involves solid-state diffusion. ${ }^{[2]}$ The plate-like $\beta$ - $\mathrm{Al}_{5} \mathrm{FeSi}$ phase was mostly found coexisting with eutectic silicon flakes and for this reason it is reasonable to assume that reaction peak 3 results from the ternary eutectic reaction $\mathrm{L} \rightarrow \mathrm{Al}+\mathrm{Si}+\beta-\mathrm{Al}_{5} \mathrm{FeSi}$. Reaction peak 3 was not observed in the cooling curve of the strontium-modified alloy. However, the fact that reaction peak 3 is not detected in the cooling curve for the unquenched strontium-modified alloy does not imply that the ternary eutectic reaction $\mathrm{L} \rightarrow \mathrm{Al}+\mathrm{Si}$ $+\beta-\mathrm{Al}_{5} \mathrm{FeSi}$ does not occur. Typically, the $\beta-\mathrm{Al}_{5} \mathrm{FeSi}$ phase coexists in association with eutectic silicon in the unquenched strontium-modified alloy, as seen in Figure 4(b). Therefore, the ternary eutectic $\mathrm{L} \rightarrow \mathrm{Al}+$ $\mathrm{Si}+\beta-\mathrm{Al}_{5} \mathrm{FeSi}$ most likely occurred, but to such a low extent that no thermal trace is detected in the cooling curve. Strontium addition can reduce the formation of $\beta-\mathrm{Al}_{5} \mathrm{FeSi}$ platelets by poisoning preferential nucleation sites for this phase ${ }^{[21,23]}$ in addition to modifying the eutectic silicon from flake-like to fibrous morphology and reducing the number of eutectic cells. ${ }^{[21,45]}$ This poisoning effect of preferential nucleation sites for $\beta-\mathrm{Al}_{5} \mathrm{FeSi}$ platelets by strontium may explain the non-appearance of a thermal arrest associated with the ternary eutectic $\mathrm{L} \rightarrow \mathrm{Al}+\mathrm{Si}+\beta-\mathrm{Al}_{5} \mathrm{FeSi}$ in the unquenched strontium-modified alloy. The larger size of $\beta-\mathrm{Al}_{5} \mathrm{FeSi}$ in the strontium modified alloys compared to the unmodified alloys suggest that this poisoning effect may occur, as shown in Figure 7(a). However, no significant differences in area fraction of $\beta-\mathrm{Al}_{5} \mathrm{FeSi}$ were found in both unmodified and strontium-modified alloys, as seen in Figure 8(a). Yu et al ${ }^{[17]}$ reported that $\beta-\mathrm{Al}_{5} \mathrm{FeSi}$ phase nucleates above the Al-Si eutectic reaction temperature while $\delta-\mathrm{Al}_{3} \mathrm{FeSi}_{2}$ phase forms during the Al-Si eutectic reaction in a high purity Al-10Si-0.3Fe alloy. The formation of pre-eutectic $\beta-\mathrm{Al}_{5} \mathrm{FeSi}$ platelets would consume iron in the liquid and reduce the amount of iron available for the formation of pro-eutectic $\beta-\mathrm{Al}_{5} \mathrm{FeSi}$. However, the formation of pre-eutectic $\beta$ - $\mathrm{Al}_{5} \mathrm{FeSi}$ platelets in this work is unlikely for two reasons; no additional thermal arrest is observed in the cooling curves between the formation of primary $\alpha-\mathrm{Al}$ dendrites and the $\mathrm{Al}-\mathrm{Si}$ eutectic reaction in both unmodified and strontium modified alloys; and no large pre-eutectic $\beta-\mathrm{Al}_{5} \mathrm{FeSi}$ platelets were observed in the samples quenched just before the start of the Al-Si eutectic reaction for both alloys.

Iron-rich $\delta-\mathrm{Al}_{3} \mathrm{FeSi}_{2}$ is typically found as thin platelets in strontium modified Al-Si alloys. ${ }^{[12-14,16-18]}$ Therefore, thin $\delta-\mathrm{Al}_{3} \mathrm{FeSi}_{2}$ platelets in strontium modified alloys can be misidentified as refined $\beta-\mathrm{Al}_{5} \mathrm{FeSi}$, as suggested in the literature. ${ }^{[13,16,18]}$ Large undercoolings, high-cooling rates and/or addition of modifier elements favor the formation of $\delta-\mathrm{Al}_{3} \mathrm{FeSi}_{2}$ phase compared to $\beta-\mathrm{Al}_{5} \mathrm{FeSi}$. ${ }^{[19]}$ The addition of strontium results in a depression of the Al-Si eutectic reaction temperature as seen in Figure 2 which indicates that the formation of pro-eutectic iron-rich phases occurs at larger undercoolings compared to the unmodified alloy, as suggested in Reference 49. Most of the studies $[12,13,16-18,40]$ that reported the formation of $\delta-\mathrm{Al}_{3} \mathrm{FeSi}_{2}$ phase were conducted on Al-Si alloys with a silicon content of $10 \mathrm{wt}$ pct and above, which is significantly larger than the alloys in this study. Additionally, the cooling rate used in those studies was significantly higher compared to the cooling rate for the unquenched samples in this study. High-silicon content and cooling rate favor the formation of $\delta-\mathrm{Al}_{3} \mathrm{FeSi}_{2}$ instead of $\beta-\mathrm{Al}_{5} \mathrm{FeSi}^{[19,51]}$ The alloys used in this study contain magnesium which may significantly change the formation of iron-rich intermetallics 
compared to magnesium-free alloys. The larger thermal arrest observed for the reaction peak 4 in the cooling curve of the strontium modified alloy suggests that the quaternary reaction $\mathrm{L} \rightarrow \mathrm{Al}+\mathrm{Si}+\pi-\mathrm{Al}_{8} \mathrm{FeMg}_{3} \mathrm{Si}_{6}+$ $\mathrm{Mg}_{2} \mathrm{Si}$ occurred to a greater extent compared to the unmodified alloy. That is, a larger fraction of $\pi-\mathrm{Al}_{8} \mathrm{FeMg}_{3} \mathrm{Si}_{6}$ and $\mathrm{Mg}_{2} \mathrm{Si}$ phases and less $\beta$ - $\mathrm{Al}_{5} \mathrm{FeSi}$ is formed in the strontium-modified alloy compared to the unmodified alloy. Slightly greater fraction of $\mathrm{Mg}_{2} \mathrm{Si}$ was observed in the strontium modified alloys compared to the unmodified alloys while $\pi-\mathrm{Al}_{8} \mathrm{FeMg}_{3} \mathrm{Si}_{6}$ phase fraction was similar in both alloys, as shown in Figure 8(a). The association of reaction peak 4 with the quaternary reaction $\mathrm{L} \rightarrow \mathrm{Al}+\mathrm{Si}+\pi-\mathrm{Al}_{8} \mathrm{FeMg}_{3} \mathrm{Si}_{6}+\mathrm{Mg}_{2} \mathrm{Si}$ is supported by the microstructural analysis where both $\pi-\mathrm{Al}_{8} \mathrm{FeMg}_{3} \mathrm{Si}_{6}$ and $\mathrm{Mg}_{2} \mathrm{Si}$ are observed close to each other (Figures 4(a) and (b)) and by the literature. ${ }^{[29,39]}$

Refinement of $\beta-\mathrm{Al}_{5} \mathrm{FeSi}$ platelets due to dissolution and fragmentation has been reported in strontium modified Al-Si alloys. ${ }^{[22,23,52,53]}$ However, a less significant effect of strontium on refinement of $\beta-\mathrm{Al}_{5} \mathrm{FeSi}$ platelets was also observed. ${ }^{[49]}$ In this study larger $\beta-\mathrm{Al}_{5} \mathrm{FeSi}$ and $\pi-\mathrm{Al}_{8} \mathrm{FeMg}_{3} \mathrm{Si}_{6}$ phases were found in the strontium modified samples which were solidified slowly during the eutectic reaction compared to the unmodified alloy, as seen in Figures 4(a) and (b) and 7(a). Similar results were reported previously in the literature. ${ }^{[23,36,52]}$ One possible explanation for this result is that strontium deactivates nucleant particles for the $\beta$ - $\mathrm{Al}_{5} \mathrm{FeSi}$ phase dispersed in the liquid which results in fewer $\beta$ - $\mathrm{Al}_{5} \mathrm{FeSi}$ platelets formed that grow larger. ${ }^{[23,52]}$ Liu et al. ${ }^{[52]}$ suggested that AlP particles nucleate $\beta-\mathrm{Al}_{5} \mathrm{FeSi}$ platelets. Cho et al. ${ }^{[21]}$ found that $\mathrm{Al}_{2} \mathrm{Si}_{2} \mathrm{Sr}$ intermetallic phase formed on AlP particles and a reduced nucleation of eutectic Al-Si cells was obtained. Interestingly, blocky intermetallics, likely $\mathrm{Al}_{2} \mathrm{Si}_{2} \mathrm{Sr}$, were observed in this study in the strontium modified alloys quenched before the start of the Al-Si eutectic reaction and halfway along the Al-Si eutectic reaction, as shown in Figure 9. However, Lu and Dahle ${ }^{[49]}$ studied the effect of phosphorous on nucleation of $\beta-\mathrm{Al}_{5} \mathrm{FeSi}$ and did not find a significant effect in an A1-7Si-0.4Mg-0.7Fe alloy. Larger $\pi-\mathrm{Al}_{8} \mathrm{FeMg}_{3} \mathrm{Si}_{6}$ phase was also found in the strontium modified alloy compared to the unmodified alloy, as shown in Figure 7(a). Most of the $\pi-\mathrm{Al}_{8} \mathrm{FeMg}_{3} \mathrm{Si}_{6}$ phase in these samples was found growing on existing $\beta-\mathrm{Al}_{5} \mathrm{FeSi}$ platelets. However, there is no clear evidence in this study and literature that the formation of $\pi-\mathrm{Al}_{8} \mathrm{FeMg}_{3} \mathrm{Si}_{6}$ phase resulted from the peritectic reaction $\mathrm{L}+\beta-\mathrm{Al}_{5} \mathrm{FeSi} \rightarrow \mathrm{Al}+\mathrm{Si}+\pi-\mathrm{Al}_{8} \mathrm{FeMg}_{3} \mathrm{Si}_{6}$ or that this phase nucleates on the $\beta-\mathrm{Al}_{5} \mathrm{FeSi}$ phase.

\section{B. Formation of Intermetallic Phases in Quenched Alloys}

Unmodified and strontium-modified alloys were quenched in water just before the start of the Al-Si eutectic reaction. This greatly increased the cooling rate produced during the $\mathrm{Al}-\mathrm{Si}$ eutectic reaction compared to the samples that were allowed to cool slowly until the end of solidification (unquenched samples). The increased cooling rate just before the start of the eutectic reaction resulted in a change in the size of the intermetallic phases formed compared to the unquenched samples for both alloys, as seen in Figures 4(c), (d) and 7(a). The iron-rich intermetallic phases formed in the alloys quenched before the start of the Al-Si eutectic reaction were smaller, particularly in the strontium modified alloy, as shown in Figures 6(e) and 7(a). A larger fraction of script-like $\pi-\mathrm{Al}_{8} \mathrm{FeMg}_{3} \mathrm{Si}_{6}$ phase was formed in the unmodified alloy quenched before the start of the Al-Si eutectic reaction at the expense of the $\beta-\mathrm{Al}_{5} \mathrm{FeSi}$ phase compared to the unquenched alloys, as shown in Figure 8(a). Additionally, the $\pi-\mathrm{Al}_{8} \mathrm{FeMg}_{3} \mathrm{Si}_{6}$ phase was mostly found isolated in the alloys quenched before the start of the Al-Si eutectic reaction, while in the unquenched samples the $\pi-\mathrm{Al}_{8} \mathrm{FeMg}_{3} \mathrm{Si}_{6}$ phase was mostly found growing on $\beta$ - $\mathrm{Al}_{5} \mathrm{FeSi}$ platelets. The increase of cooling rate decreases the fraction of $\beta-\mathrm{Al}_{5} \mathrm{FeSi}$ phase while the fraction of $\pi-\mathrm{Al}_{8} \mathrm{FeMg}_{3} \mathrm{Si}_{6}$ phase increases. ${ }^{[23,31]}$ In the unmodified alloys, eutectic silicon grows as an interconnected plate-like network. The branching of silicon plates that occurs during growth can result in entrapment of solute-enriched liquid between silicon plates. ${ }^{\text {[5] }}$ At high-cooling rates, the start temperature for the formation of $\beta-\mathrm{Al}_{5} \mathrm{FeSi}$ phase is decreased to a point that the composition of the remaining liquid can favor the formation of other phases. ${ }^{[22]}$ Therefore, the high-cooling rate produced in the unmodified alloy quenched before the start of the Al-Si eutectic reaction could decrease the $\beta$ - $\mathrm{Al}_{5} \mathrm{FeSi}$ phase formation temperature to such an extent that the composition of the remaining liquid would favor the formation of $\pi-\mathrm{Al}_{8} \mathrm{FeMg}_{3} \mathrm{Si}_{6}$ phase instead of $\beta-\mathrm{Al}_{5} \mathrm{FeSi}$. It is reasonable to assume that the $\pi-\mathrm{Al}_{8} \mathrm{FeMg}_{3} \mathrm{Si}_{6}$ formed in the last solidified liquid located between the fine silicon plate branches will grow smaller in the unmodified alloy quenched before the start of the Al-Si eutectic reaction compared to the unquenched sample.

In the strontium-modified alloy quenched before the start of the Al-Si eutectic reaction, the only intermetallic phase detected was a fine needle-like $\pi$ - $\mathrm{Al}_{8} \mathrm{FeMg}_{3} \mathrm{Si}_{6}$ phase located at the Al-Si-eutectic cell boundaries, as shown in Figures 4(d) and 6(e) through (h). Yu et al. ${ }^{[16]}$ reported the formation of Chinese-script intermetallic phase in an unmodified Al-10Si-0.3Fe alloy while the intermetallic phases were mostly needle-like (in two dimensions) in the strontium modified alloy. Additionally, the Chinese-script iron-rich phase obtained in the unmodified alloy was uniformly dispersed within the eutectic regions while the needle-like iron-rich phase was located at the eutectic cell boundaries. ${ }^{[16]}$ These observations show great similarities with the results obtained in this study for the unmodified and strontium modified alloys quenched before the start of the Al-Si eutectic reaction. It is important to notice that the silicon and iron contents in the alloy used by $\mathrm{Yu}$ et $a l^{[16]}$ were higher, while the strontium content was similar to this work. Additionally, in that study the Chinese-script iron-rich phase predominantly found in the unmodified alloy was identified as $\alpha-\mathrm{Al}_{14} \mathrm{Fe}_{3} \mathrm{Si}_{2}$ while the needle-like iron-rich phase in the strontium modified alloy was $\delta$ - $\mathrm{Al}_{3} \mathrm{FeSi}^{\left[{ }^{16]}\right.}$ The similarities in morphology and distribution of the iron-rich intermetallic phases in the work 
by $\mathrm{Yu}$ et al. ${ }^{[16]}$ and that obtained for the strontium-modified alloy quenched before the start of the Al-Si eutectic in this study suggest that the formation mechanism of the iron-rich phases is likely similar. Initially the eutectic Al-Si cells grow radially and a coupled eutectic solidification front of $\mathrm{Al}$ and $\mathrm{Si}$ phases is stablished in the center of the grain that is nearly free of iron-rich phases. ${ }^{[15,16,54]}$ During the advance of the solidification front, solute is rejected by the solid-liquid interface front. This rejected solute accumulates at the solidification front and can result in the formation of instabilities at the solid-liquid interface. ${ }^{[18]}$ Consequently, iron-rich intermetallics can form between those instabilities and become entrapped in isolated pockets within the growing eutectic cell. ${ }^{[18]}$ However, no isolated iron-rich intermetallics were observed located within eutectic cells in this study for the strontium-modified samples quenched before the start of the Al-Si eutectic reaction. The solid-liquid interface velocity can vary during solidification which results in variations of silicon morphology within the same eutectic cell in strontium-modified alloys. ${ }^{[54]}$ In this study, coarser Al-Si eutectic and fine $\pi-\mathrm{Al}_{8} \mathrm{FeMg}_{3} \mathrm{Si}_{6}$ phase formed at the Al-Si eutectic cell boundaries, as shown in Figures 4(d) and 6(e) through (h). The coarser Al-Si eutectic observed near eutectic cell boundaries compared to the eutectic cell center was observed in another study of a strontium-modified Al-10Si alloy. ${ }^{[16]}$ This microstructural change within the same eutectic cell may result from the high-solute concentration at the solid-liquid interface and/or growth rate of the eutectic cell towards the end of solidification. ${ }^{[18]}$ The accumulation of iron and magnesium that occurs towards the end of solidification can result in the formation of $\pi-\mathrm{Al}_{8} \mathrm{FeMg}_{3} \mathrm{Si}_{6}$ in the last liquid solidified at the eutectic cell boundaries, as shown in Figure 4(d). Additionally, the size and morphology of the $\pi-\mathrm{Al}_{8} \mathrm{FeMg}_{3} \mathrm{Si}_{6}$ phase is dictated by the limited amount of liquid existing between adjacent eutectic cells. This may explain the small size and needle-like shape (in two dimensions) of the $\pi-\mathrm{Al}_{8} \mathrm{FeMg}_{3} \mathrm{Si}_{6}$ phase that forms in the strontium modified samples quenched before the start of the Al-Si eutectic reaction.

\section{Intermetallic Phase Formation in SSM Al-7Si-0.3Mg Castings}

In this work, the Rheometal ${ }^{\mathrm{TM}}$ process was used to produce SSM Al-7Si- $0.3 \mathrm{Mg}$ castings. In this process, the solidification starts during the slurry preparation with the formation of primary near-globular $\alpha$-Al crystals dispersed in the liquid. After preparation, the slurry is poured into the shot sleeve where the solidification can progress to some extent on/near the relatively cold shot sleeve walls. Next, the slurry is injected into the die cavity and solidification occurs at high-cooling rate with the growth of the slurry $\alpha$-Al crystals, nucleation and growth of in-cavity solidified crystals and ends with the formation of the eutectic. Figure 10(b) shows the microstructure of the SSM Al-7Si-0.3Mg in the T5 condition. The microstructure of SSM casting in the as-cast condition is very similar to that obtained in the
T5 condition. The microstructure consists of primary $\alpha$-Al globules, modified $\mathrm{Al}-\mathrm{Si}$ eutectic and a minor fraction of intermetallic phases located at the eutectic cell boundaries, as shown in Figures 10(a) and 10(b). The eutectic microstructure obtained in the SSM casting was very similar compared to the strontium-modified alloy quenched before the start of the Al-Si eutectic reaction where the iron-rich intermetallic phases containing magnesium formed at the cell boundaries, as shown in Figures 11(a) through (d). Additionally, no significant differences were found on size and area fraction of $\pi-\mathrm{Al}_{8} \mathrm{FeMg}_{3} \mathrm{Si}_{6}$ phase in the SSM casting in the T5 condition compared to the strontium modified alloy quenched before the start of the Al-Si eutectic reaction, as shown in Figures 7 and 8. Therefore, the similarities of intermetallic phase morphology, distribution and composition suggests that the formation mechanism of the intermetallic phases is similar for the modified quenched sample and the SSM castings.

The microstructure of the SSM casting in the T6 condition consisted of primary $\alpha$-Al globules, coarse and spheroidized eutectic silicon and very fine intermetallic phases located within the eutectic regions, as seen in Figure 10(c). The intermetallic phase identified in this sample was $\beta-\mathrm{Al}_{5} \mathrm{FeSi}$, as the magnesium concentration was lower compared to the surroundings, as shown in Figures 11(e) through (h). This indicates that the $\pi-\mathrm{Al}_{8} \mathrm{FeMg}_{3} \mathrm{Si}_{6}$ phase in the as-cast condition transformed into $\beta-\mathrm{Al}_{5} \mathrm{FeSi}$ and released magnesium into solution. No reaction peak is observed to occur at lower temperatures than the main $\mathrm{Al}-\mathrm{Si}$ eutectic reaction peak in the DSC for the first melting cycle of the SSM casting in the T6 condition, Figure 12, suggesting that most of the $\pi-\mathrm{Al}_{8} \mathrm{FeMg}_{3} \mathrm{Si}_{6}$ has transformed into $\beta-\mathrm{Al}_{5} \mathrm{FeSi}$. Smaller $\pi-\mathrm{Al}_{8} \mathrm{FeMg}_{3} \mathrm{Si}_{6}$ was obtained in the strontium modified alloy compared to the unmodified alloy quenched before the start of the Al-Si eutectic reaction, as shown in Figure 7(a). Additionally, $\beta-\mathrm{Al}_{5} \mathrm{FeSi}$ platelets were observed in the unmodified alloy which is considered the most detrimental iron-rich phase for mechanical properties and is not affected by solution treatment. ${ }^{[38]}$ Finer $\pi-\mathrm{Al}_{8} \mathrm{FeMg}_{3} \mathrm{Si}_{6}$ phase results in less solution treatment time required for a complete transformation of $\pi-\mathrm{Al}_{8} \mathrm{FeMg}_{3} \mathrm{Si}_{6}$ into very fine $\beta-\mathrm{Al}_{5} \mathrm{FeSi}$ plates and release of magnesium into solution. ${ }^{[31]}$ This indicates that there are great advantages of using strontium modification and a casting process that produces a high-cooling rate during the eutectic reaction, such as SSM casting.

\section{CONCLUSIONS}

The formation of iron-rich intermetallics during solidification was studied in unquenched and quenched unmodified and strontium modified Al-7Si- $0.3 \mathrm{Mg}$ alloys. Strontium addition changed the nucleation and growth conditions resulting in a greater fraction of $\pi-\mathrm{Al}_{8} \mathrm{FeMg}_{3} \mathrm{Si}_{6}$ formed to the detriment of $\beta-\mathrm{Al}_{5} \mathrm{FeSi}$ phase in the alloys quenched before the start of the Al-Si eutectic reaction. For the unquenched alloys, larger $\beta-\mathrm{Al}_{5} \mathrm{FeSi}$ platelets and Chinese script-like 
$\pi-\mathrm{Al}_{8} \mathrm{FeMg}_{3} \mathrm{Si}_{6}$ phase were observed in the strontium-modified alloy compared to the unmodified alloy.

Finer $\pi-\mathrm{Al}_{8} \mathrm{FeMg}_{3} \mathrm{Si}_{6}$ phase that appeared as thin platelets was formed in the strontium-modified alloy compared to the Chinese script-like $\pi-\mathrm{Al}_{8} \mathrm{FeMg}_{3} \mathrm{Si}_{6}$ and plate-like $\beta-\mathrm{Al}_{5} \mathrm{FeSi}$ phases formed in the unmodified alloy quenched before the start of the Al-Si eutectic reaction. The iron-rich intermetallic phases formed in the unmodified alloy quenched before the start of the Al-Si eutectic reaction were found uniformly distributed in the eutectic regions, while in the strontium-modified alloy the intermetallic phases were located at the eutectic cell boundaries.

The microstructure of the strontium-modified SSM Al- $7 \mathrm{Si}-0.3 \mathrm{Mg}$ castings in the as-cast and $\mathrm{T} 5$ conditions consisted of primary $\alpha$-Al globules, modified $\mathrm{Al}-\mathrm{Si}$ eutectic and a minor fraction of intermetallic phases located at the eutectic cell boundaries. The similarities in intermetallic phase morphology and distribution in the SSM casting and the strontium-modified quenched sample suggest that the formation mechanism of the intermetallic phases was similar.

During the T6 heat treatment, most of the $\pi-\mathrm{Al}_{8} \mathrm{FeMg}_{3} \mathrm{Si}_{6}$ phase transformed into $\beta-\mathrm{Al}_{5} \mathrm{FeSi}$ platelets in the SSM casting. These $\beta-\mathrm{Al}_{5} \mathrm{FeSi}$ platelets were smaller and more dispersed in the eutectic regions compared to the $\pi-\mathrm{Al}_{8} \mathrm{FeMg}_{3} \mathrm{Si}_{6}$ phase of SSM castings in the as-cast and $\mathrm{T} 5$ conditions.

\section{ACKNOWLEDGMENTS}

This work was funded by VINNOVA under the FatSS project (Dnr 2014-05096) and it is part of the LIGHTER programme, Knowledge Foundation (Dnr. 20100280) and Compcast Plus (Dnr. 20170066). The authors are also grateful for the support from Volvo Lastvagnar AB, COMPtech AB, Fueltech AB.

\section{OPEN ACCESS}

This article is distributed under the terms of the Creative Commons Attribution 4.0 International License (http://creativecommons.org/licenses/by/4.0/), which permits unrestricted use, distribution, and reproduction in any medium, provided you give appropriate credit to the original author(s) and the source, provide a link to the Creative Commons license, and indicate if changes were made.

\section{REFERENCES}

1. L.F. Mondolfo: Aluminium Alloys: Structure and Properties, 1976.

2. B. Zhang, D.R. Poirier, and W. Chen: Metall. Mater. Trans. A, 1999, vol. 30A, pp. 2659-66.

3. S. Dezecot and M. Brochu: Int. J. Fatigue, 2015, vol. 77, pp. $154-59$.

4. M. Blad, B. Johannesson, P. Nordberg, and J. Winklhofer: in Semi-Solid Processing of Alloys and Composites XIV, vol. 256, Trans Tech Publications, 2016, pp. 328-33.
5. X.G. Hu, Q. Zhu, S.P. Midson, H.V. Atkinson, H.B. Dong, F. Zhang, and Y.L. Kang: Acta Mater., 2017, vol. 124, pp. 446-55.

6. Q.G. Wang, D. Apelian, and D.A. Lados: J. Light Met., 2001, vol. 1 , pp. $73-84$

7. H.R. Ammar, A.M. Samuel, and F.H. Samuel: Mater. Sci. Eng. A, 2008, vol. 473, pp. 65-75.

8. Q.G. Wang, D. Apelian, and D.A. Lados: J. Light Met., 2001, vol. 1, pp. 85-97.

9. J.Z. Yi, Y.X. Gao, P.D. Lee, and T.C. Lindley: Mater. Sci. Eng. A, 2004, vol. 386, pp. 396-407.

10. R. Chen, Q. Xu, H. Guo, Z. Xia, Q. Wu, and B. Liu: Mater. Sci. Eng. A, 2017, vol. 685, pp. 391-402.

11. M. Yildirim and D. Özyürek: Mater. Des., 2013, vol. 51, pp. $767-74$.

12. M.V. Kral, H.R. McIntyre, and M.J. Smillie: Scr. Mater., 2004, vol. 51, pp. 215-19.

13. M.V. Kral, P.N.H. Nakashima, and D.R.G. Mitchell: Metall. Mater. Trans. A, 2006, vol. 37, pp. 1987-97.

14. M.V. Kral: Mater. Lett., 2005, vol. 59, pp. 2271-76.

15. M. Timpel, N. Wanderka, B.S. Murty, and J. Banhart: Acta Mater., 2010, vol. 58, pp. 6600-08.

16. J.M. Yu, N. Wanderka, G. Miehe, and J. Banhart: Intermetallics, 2016, vol. 72, pp. 53-61.

17. J.M. Yu, N. Wanderka, A. Rack, R. Daudin, E. Boller, H. Markötter, A. Manzoni, F. Vogel, T. Arlt, I. Manke, and J. Banhart: Acta Mater., 2017, vol. 129, pp. 194-202.

18. M. Timpel, N. Wanderka, R. Grothausmann, and J. Banhart: $J$. Alloys Compd., 2013, vol. 558, pp. 18-25.

19. W. Khalifa, F.H. Samuel, and J.E. Gruzleski: Metall. Mater. Trans. A, 2003, vol. 34A, pp. 807-25.

20. Y.S. Choi, J.S. Lee, W.T. Kim, and H.Y. Ra: J. Mater. Sci., 1999, vol. 34, pp. 2163-68.

21. Y.H. Cho, H.C. Lee, K.H. Oh, and A.K. Dahle: Metall. Mater. Trans. A, 2009, vol. 40A, pp. 1009-10.

22. A.M. Samuel, A. Pennors, C. Villeneuve, F.H. Samuel, H.W. Doty, and S. Valtierra: Int. J. Cast Met. Res., 2000, vol. 13, pp. $231-53$.

23. A.M. Samuel, F.H. Samuel, and H.W. Doty: J. Mater. Sci., 1996, vol. 31 , pp. 5529-39.

24. X. Cao and J. Campbell: Metall. Mater. Trans. A, 2003, vol. 34A, pp. 1409-20.

25. J. Campbell: Metall. Mater. Trans. A, 2009, vol. 40A, pp. 1009-10.

26. C. Puncreobutr, A.B. Phillion, J.L. Fife, P. Rockett, A.P. Horsfield, and P.D. Lee: Acta Mater., 2014, vol. 79, pp. 292-303.

27. Q.G. Wang and C.J. Davidson: J. Mater. Sci., 2001, vol. 36, pp. $739-50$.

28. B. Closset and J.E. Gruzleski: Metall. Mater. Trans. A, 1982, vol. 13A, pp. 945-51.

29. Q. Tang, J. Zhao, T. Wang, J. Chen, and K. He: J. Alloys Compd., 2018, vol. 741, pp. 161-73.

30. D. Casari, T.H. Ludwig, M. Merlin, L. Arnberg, and G.L. Garagnani: Mater. Sci. Eng. A, 2014, vol. 610, pp. 414-26.

31. E. Sjölander and S. Seifeddine: Metall. Mater. Trans. A, 2014, vol. 45A, pp. 1916-27.

32. K.Y. Wen, W. Hu, and G. Gottstein: Mater. Sci. Technol., 2003, vol. 19 , pp. 762-68.

33. S. Menargues, E. Martín, M.T. Baile, and J.A. Picas: Mater. Sci. Eng. A, 2015, vol. 621, pp. 236-42.

34. B. Mingo, R. Arrabal, A. Pardo, E. Matykina, and P. Skeldon: Mater. Charact., 2016, vol. 112, pp. 122-28.

35. J.A. Taylor, J. Barresi, M.J. Couper, and D.H. StJohn: in Aluminium Alloys - Their Physical and Mechanical Properties, vol. 331, Trans Tech Publications, 2000, pp. 277-82.

36. E.A. Elsharkawi, E. Samuel, A.M. Samuel, and F.H. Samuel: $J$. Mater. Sci., 2010, vol. 45, pp. 1528-39.

37. G. Gustafsson, T. Thorvaldssons, and G.L. Dunlop: Metall. Mater. Trans. A, 1986, vol. 17A, pp. 45-52.

38. J.A. Taylor: Procedia Mater. Sci., 2012, vol. 1, pp. 19-33.

39. L. Bäckerud, G. Chai, and J. Tamminen: Solidification Characteristics of Aluminum Alloys, Volume 2: Foundry Alloys, AFS/ SKANALUMINIUM, Stockholm, 1990.

40. J.M. Yu, N. Wanderka, A. Rack, R. Daudin, E. Boller, H. Markötter, A. Manzoni, F. Vogel, T. Arlt, I. Manke, and J. Banhart: J. Alloys Compd., 2018, vol. 766, pp. 818-27. 
41. I. Öztürk, G. Hapçı Ağaoğlu, E. Erzi, D. Dispinar, and G. Orhan: J. Alloys Compd., 2018, vol. 763, pp. 384-91.

42. O. Granath, M. Wessén, and H. Cao: Int. J. Cast Met. Res., 2008, vol. 21 , pp. $349-56$.

43. ASTM E562-11: ASTM Int., 2011, pp. 1-7.

44. G.L. Brollo, C.T.W. Proni, L.C. de Paula, and E.J. Zoqui: Thermochim. Acta, 2017, vol. 651, pp. 22-33.

45. S.D. McDonald, K. Nogita, and A.K. Dahle: Acta Mater., 2004, vol. 52 , pp. $4273-80$.

46. A.K. Dahle, K. Nogita, J.W. Zindel, S.D. McDonald, and L.M. Hogan: Metall. Mater. Trans. A, 2001, vol. 32A, pp. 949-60.

47. C.H. Caceres, C.J. Davidson, Q.G. Wang, and J.R. Griffiths: Metall. Mater. Trans. A, 1999, vol. 30A, pp. 2611-18.

48. N.A. Belov, D.G. Eskin, and A.A. Aksenov: Multicomponent Phase Diagrams: Applications for Commercial Aluminum Alloys, Elsevier B.V., 2005.
49. L. Lu and A.K. Dahle: Metall. Mater. Trans. A, 2005, vol. 36A, pp. 819-35.

50. M. Tebib, A.M. Samuel, F. Ajersch, and X.G. Chen: Mater. Charact., 2014, vol. 89, pp. 112-23.

51. W. Khalifa, F.H. Samuel, J.E. Gruzleski, H.W. Doty, and S. Valtierra: Metall. Mater. Trans. A, 2005, vol. 36A, pp. 1017-32.

52. L. Liu, A.M.A. Mohamed, A.M. Samuel, F.H. Samuel, H.W. Doty, and S. Valtierra: Metall. Mater. Trans. A, 2009, vol. 40A, pp. 2457-69.

53. F.H. Samuel, A.M. Samuel, P. Ouellet, and H.W. Doty: Metall. Mater. Trans. A, 1998, vol. 29A, pp. 2871-84.

54. S.D. McDonald, A.K. Dahle, J.A. Taylor, and D.H. StJohn: Metall. Mater. Trans. A, 2004, vol. 35A, pp. 1829-37.

Publisher's Note Springer Nature remains neutral with regard to jurisdictional claims in published maps and institutional affiliations. 